\title{
Sorghum-Phosphate Solubilizers Interactions: Crop Nutrition, Biotic Stress Alleviation, and Yield Optimization
}

OPEN ACCESS

Edited by:

Giuseppe Colla,

University of Tuscia, Italy

Reviewed by:

Kanchan Vishwakarma,

Swedish University of Agricultural

Sciences, Sweden

Mohamed Sheteiwy,

Mansoura University, Egypt

${ }^{*}$ Correspondence:

Bilal Ahmed

bilal22000858@yu.ac.kr

Asfa Rizvi

asfarizvi09@gmail.com

Specialty section:

This article was submitted to

Plant Abiotic Stress,

a section of the journal

Frontiers in Plant Science

Received: 24 July 2021 Accepted: 01 November 2021

Published: 01 December 2021

Citation:

Rizvi A, Ahmed B, Khan MS, Umar S and Lee J (2021) SorghumPhosphate Solubilizers Interactions:

Crop Nutrition, Biotic Stress Alleviation, and Yield Optimization.

Front. Plant Sci. 12:746780.

doi: 10.3389/fp/s.2021.746780

\begin{abstract}
Asfa Rizvi", Bilal Ahmed ${ }^{2 *}$, Mohammad Saghir Khan ${ }^{3}$, Shahid Umar' and Jintae Lee $^{2}$
${ }^{1}$ Department of Botany, School of Chemical and Life Sciences, Jamia Hamdard, New Delhi, India, ${ }^{2}$ School of Chemical Engineering, Yeungnam University, Gyeongsan, South Korea, ${ }^{3}$ Department of Agricultural Microbiology, Faculty of Agricultural Sciences, Aligarh Muslim University, Aligarh, India
\end{abstract}

Sweet sorghum [Sorghum bicolor (L.) Moench] is a highly productive, gluten-free cereal crop plant that can be used as an alternative energy resource, human food, and livestock feed or for biofuel-ethanol production. Phosphate fertilization is a common practice to optimize sorghum yield but because of high cost, environmental hazards, and soil fertility reduction, the use of chemical $P$ fertilizer is discouraged. Due to this, the impetus to search for an inexpensive and eco-friendly microbiome as an alternative to chemical $P$ biofertilizer has been increased. Microbial formulations, especially phosphate solubilizing microbiome (PSM) either alone or in synergism with other rhizobacteria, modify the soil nutrient pool and augment the growth, P nutrition, and yield of sorghum. The use of PSM in sorghum disease management reduces the dependence on pesticides employed to control the phytopathogens damage. The role of PSM in the sorghum cultivation system is, however, relatively unresearched. In this manuscript, the diversity and the strategies adopted by PSM to expedite sorghum yield are reviewed, including the nutritional importance of sorghum in human health and the mechanism of $P$ solubilization by PSM. Also, the impact of solo or composite inoculations of biological enhancers (PSM) with nitrogen fixers or arbuscular mycorrhizal fungi is explained. The approaches employed by PSM to control sorghum phytopathogens are highlighted. The simultaneous bio-enhancing and biocontrol activity of the PS microbiome provides better options for the replacement of chemical $P$ fertilizers and pesticide application in sustainable sorghum production practices.

Keywords: sorghum, phosphate solubilizers, microbiome, phytopathogens, antagonists, P-nutrition

\section{INTRODUCTION}

The constantly increasing human populations and regularly declining agricultural soils have placed extra pressure on sustainable agriculture systems to eliminate human food hunger worldwide (Díaz-Rodríguez et al., 2020). Globally, P fertilization is a common practice to improve sorghum production (Gemenet et al., 2016), but the intemperate application or unrelenting long-term utilization of chemical-P fertilizers cause environmental pollution and 
reduce soil quality (Alori et al., 2017; Li et al., 2020). The efficiency of $\mathrm{P}$ solubilizer is very low (15-20\%) due to its rapid fixation in acidic and alkaline soils, both of which are predominant worldwide (Aziz et al., 2014). Though the majority of global soils contain sufficient reserves of total $\mathrm{P}$, most of it remains inaccessible, and soils thus become deficient in $\mathrm{P}$. So, to maintain sorghum production, $\mathrm{P}$ fertilizers are applied regularly. The high cost of chemical-P fertilizer acts as a motivator in the quest for an alternative where naturallyoccurring $\mathrm{P}$ sources such as rock phosphate (RP) serve as a $\mathrm{P}$ reservoir. Regrettably, $\mathrm{RP}$ is not easily available to plants in soils with a $\mathrm{pH}>5.5-6$, and farmers thus cannot use RP in sorghum fields (Gurdeep and Reddy, 2015). However, the microbial fertilizers, especially phosphate biofertilizers, augment the P use efficiency (PUE) and thereby improve plant P uptake. Collectively, the phosphate solubilizing microbiome (PSM) represents a group of soil organisms that make $\mathrm{P}$ available to plants from both inorganic and organic sources by solubilizing and mineralizing complex P compounds (Zaidi et al., 2009; Chawngthu et al., 2020). Among PSM inhabiting a particular environment, bacteria (Rezakhani et al., 2020), fungi (Elfiati et al., 2021), and actinomycetes (Saif et al., 2014) supply mineral nutrients especially $\mathrm{P}$ to various food crops including sorghum growing in different agroclimatic regions worldwide (Abawari et al., 2020; Chen et al., 2021). The PSM intervention in sorghum cultivation practices seems to be an incredibly attractive and highly promising approach to ameliorate sorghum production in P-deficient soil (dos Santos et al., 2017). Apart from supplying $\mathrm{P}$, PSM plays an important role in suppressing the damaging impact of phytopathogens causing severe sorghum yield losses (Gopalakrishnan et al., 2015; Mitra et al., 2020). The PSM-mediated management of $\mathrm{P}$ nutrition and sorghum phytopathogens is considered an inexpensive and environmentally friendly biotechnological approach and appears to be a realistic substitute to chemical $\mathrm{P}$ fertilizers and hazardous pesticides (Saraf et al., 2014; Kumar et al., 2020). However, due to the competition among/between indigenous/introduced microbiome, soil environment, and other factors, the competence of PSM to survive and colonize in the rhizosphere is greatly challenged (Soumare et al., 2020). Despite this, the PSM, when applied as microbiological formulations in field/greenhouse, has been found to enhance the growth and yield of many food crops (Ahmed et al., 2017; Batool and Iqbal, 2019), including sorghum (Vijayalakshmi et al., 2020), by various direct and indirect mechanisms (Khan et al., 2014; Herrera-Quiterio et al., 2020).

Sorghum, a multipurpose cereal crop belonging to the family Poaceae, ranks fourth in terms of worldwide production after wheat, rice, and corn (Shoemaker and Bransby, 2010; Kumar et al., 2017a). It is typically cultivated in the semi-arid tropics (Almodares and Hadi, 2009) and has several economically important potential uses such as food (grain), feed (grain and biomass), biofuel (ethanol production), fiber (paper), fermentation (methane production), and fertilizer (Hasibuan and Nazir, 2017; Dar et al., 2018). Due to excessive pressure on the production of rice for human consumption, there is an urgent need to search for any nutrition-rich alternative food substitutes for rice to satisfy human food demands. Sweet sorghum in this context can serve as a potential food alternative in many countries (Marles et al., 2018). Different approaches like crop rotation, use of resistant cultivars, and agrochemicals to combat phytopathogens have been adopted to enhance the yield and quality of sweet sorghum, but due to several reasons, especially the cost, technical difficulties, emergence of resistance among pathogens against toxic chemicals, residual toxicity to non-target organisms, or environmental pollution, the implementation of such methods/chemicals is discouraged in sorghum cultivation practices. The utilization of microbiological fertilizers particularly PSM is an alternative option to plant growth and production of sweet sorghum under biotic stress conditions. However, little research has been conducted and very little information is available on the ameliorative role of PSM in relation to the growth and yield of sorghum, particularly under biotic stressed conditions. Acknowledging the importance of human food and lack of information on the role of PSM in sorghum production in high throughput agricultural practices, this review attempts to provide the latest information on the biodiversity and physiological variations of PSM and its importance in sorghum $P$ nutrition, biotic stress alleviation and yield optimization/stability in changing agro-ecosystems worldwide. This review further explains the mechanistic basis of disease suppression and highlights the potential role of single and/or composite PSM formulations in sorghum-soil systems. The understanding of the relationship between the PSM and related rhizobacteria and arbuscular mycorrhizal fungi may help in better management of $\mathrm{P}$ fertilization and biotic stress alleviation in sorghum growing in different agrosystems while reducing the risk of chemical pollution.

\section{SORGHUM: FOOD, NUTRITIONAL COMPOSITION, AND HUMAN HEALTH}

Sorghum, which is naturally gluten free, is a major cereal grown as a food and feed crop (Kumar et al., 2017b; Zhao et al., 2019). Sorghum is known by different names, such as great millet and guinea corn in West Africa; kafir corn in South Africa; dura in Sudan; jowar in India, and kaoliang in China. Among sorghum-producing countries, the United States is a major sorghum producer, but only a small fraction of grain is consumed here as human food; instead, it is mainly used as animal fodder. Worldwide, sorghum is consumed in various forms, such as alcoholic and non-alcoholic beverages, baked bread, tortillas, porridges, couscous, gruel, steam-cooked products, expanded snacks, cookies, etc. (Murty and Subramanian, 1982). Sorghum can also be processed into starch, flour, grits, and flakes and is used to produce a wide range of industrial products. Due to its nutritional importance, sorghum is incorporated into the human diet more specifically for people who are intolerant to wheat (Kulamarva et al., 2009). It is consumed mostly in northern China, India, and southern Russia, where about $85 \%$ of the crops are consumed directly as human food (Dicko et al., 2006).

Nutritionally, sweet sorghum is quite high (62\%) in carbohydrates (Barcelos et al., 2016) and has a higher energy output than sugarcane, sugar beet, corn, and wheat 
(Dar et al., 2018). Sorghum provides important minerals, vitamins, protein, and micronutrients essential for optimal health, growth, and development (Awika and Rooney, 2004; Kulamarva et al., 2009). Recently (Tasie and Gebreyes, 2020), observed proximate composition values such as moisture, ash, crude fat, crude fiber, and crude protein, and $\mathrm{CHO}$ in different sorghum varieties, which varied from 9.66 to $12.94,1.12$ to $2.29,2.48$ to $4.60,2.17$ to $8.59,8.20$ to 16.48 , and 67.56 to 76.42 , respectively. The highest mineral content in sorghum varieties was (mg/100g): P (368), Na (6), Mg (208), K (314), $\mathrm{Ca}$ (67), Fe (14), and $\mathrm{Zn}(6)$. The maximum tannin was recorded in Lalo $(3,337 \mathrm{mg} / 100 \mathrm{~g})$ and Dano $(2,474 \mathrm{mg} / 100 \mathrm{~g})$. Based on the high mineral value, sorghum varieties such as Miskir, Abshir, ESH-1, Meko-1, Red Swazi, and Karimtams can be considered for food product development. Sorghum also contains various phenolics like flavonoids (Shahidi and Naczk, 1995), which inhibit tumor development (Awika and Rooney, 2004), and antioxidants, which make the grain suitable for producing functional foods. It is a gluten-free cereal, which has importance in the occurrence of Celiac Disease (CD), an immunological response to gluten intolerance. The starches and sugars in sorghum are released more slowly than in other cereals (Léder, 2004) and it is thus beneficial for diabetic persons (Toomey, 1988).

\section{WHY IS PSM SO IMPORTANT IN SORGHUM PLANT SYSTEMS?}

Chemical fertilization (e.g., NPK) in agriculture is documented as a successful practice to manage soil fertility and concurrently to increase the quality and yield of cereal crops (Mojid et al., 2012; Saïdou et al., 2018), including sorghum (Sebnie et al., 2020), in different agro-ecological regions. Among plant nutrients, $\mathrm{P}$ is the major nutrient after $\mathrm{N}$ and is the second most deficient plant nutrient (Munir et al., 2004). Under a P-deficient environment, plants show altered growth and metabolism, and a reduction from 5 to $15 \%$ in crop yield has been reported (Shenoy and Kalagudi, 2005). So, to overcome the low P availability and to allow sorghum plants to grow normally, $\mathrm{P}$ fertilizers are used in cultivation practices (Roy and Khandaker, 2010). Sorghum requires high levels of chemical fertilizer for optimal growth, which causes a shift in the soil microbial community (Chu et al., 2007; Wang et al., 2018) and environmental degradation leading to human health problems (Adesemoye and Kloepper, 2009; Kang et al., 2011) These problems accentuate the need for new technologies in sorghum production systems to achieve sustainable production systems. The PSM of plantgrowth-promoting microbes is of particular interest as it can, either alone or in combination with other related PGPR/AM-fungi, reduce the adverse impact of chemical fertilizers and simultaneously enhances plants' tolerance to environmental stress (Bhardwaj et al., 2014). Additionally, the PSM promotes root morphogenesis and gradually increases plant height, stem diameter, number of leaves per plant, leaf area, and yield along with protecting plants from phytopathogens attack (Pandey and Gupta, 2020). Also, P supplied either through solubilization or mineralization by PSM participates in cell division, growth of new tissues and nucleic acid structure, protein synthesis regulation, respiration, signal transduction, macro-molecular biosynthesis, phospholipids, carbon metabolism and a wide range of enzymes, energy transfer, and photosynthesis (Kouas et al., 2005; Hameeda et al., 2008). To fulfill P demands, the PSM has been found to be very useful (Qarni et al., 2021). The PSM-sorghum plant synergy could, therefore, be of great practical importance in the management of $\mathrm{P}$ nutrition, biotic stress, and yield optimization. Once developed, the PSM formulation benefits sorghum in several ways due to its ability to (i) release $\mathrm{P}$ nutrients slowly and as per the need of plants; (ii) complement other minerals; (iii) supply essential agroactive biological enhancers to plants; and (iv) alleviate biotic stress (Khan et al., 2014; García-Fraile et al., 2015; Yadav and Sarkar, 2019). Broadly, the utilization of microbes mediated rock phosphate solubilization has multiple advantages over conventional chemical P fertilizers in sorghum cultivation practices. These advantages are as follows: (i) the PSM-based formulations are safer than chemical fertilizers; (ii) there is no chance of deposition of either toxic materials or microbiome in the food chain; (iii) the self-replicating ability of microbes evades the requirement for repetitive application; and (iv) they reduce dependence on pesticides. Put together, the PSM along with RP could be an incredibly strong strategy to advance the biological and physicochemical fertility of the soil, which eventually enhances the sorghum production at a low cost. While the literature regarding PGPR interactions with the top three cereals (maize, wheat, and rice) is quite sizeable, a search conducted using the words "PSM" and "sorghum" as keywords revealed very few papers in the scientific literature. Also, when searching PSM and sorghum diseases, very few scientific studies are available. Collectively, the amount of information regarding the interactions between PSM (bacteria/ fungi/actinomycetes) and sweet sorghum is limited.

\section{OVERVIEW OF PSM: DEFINITION, BIODIVERSITY, AND P-SOLUBILIZATION}

A group of beneficial soil microbiomes, including bacteria, fungi, and actinomycetes, capable of mineralizing/solubilizing complex $\mathrm{P}$ into soluble forms are termed phosphate-solubilizing microorganisms (Tian et al., 2021). The PSM has been recovered from different ecological habitats (Table 1) using standard microbiological methods (Figure 1). Pseudomonas and Bacillus among bacteria and Aspergillus and Penicillium among fungi are the most efficacious P solubilizers (Li et al., 2016; Zhu et al., 2018). P-solubilizing fungi (PSF) are better P solubilizers than other PSMs due to their ability to do the following: (i) retain a P-dissolving ability after repeated subculturing; (ii) traverse longer distances more easily in any environment; and (iii) produce more organic acids (Venkateswarlu et al., 1984). Among mineral phosphate solubilization (mps) mechanisms, the organic acid (OA) theory is the most widely accepted mechanism of solubilization and supply of $\mathrm{P}$ to plants (Table 2). The OA lowers the $\mathrm{pH}$ of the environment and causes discharge of $\mathrm{P}$ ions from the $\mathrm{P}$ mineral by $\mathrm{H}^{+}$exchange for $\mathrm{Ca}^{2+}$ (Goldstein et al., 1993). The variation in $\mathrm{pH}$ and the amount of $\mathrm{P}$ solubilized 
TABLE 1 | Phosphate solubilizing microbiome biodiversity in different agroecological habitat.

\begin{tabular}{|c|c|c|c|}
\hline PSM groups & Source/Origin & Media used & References \\
\hline \multicolumn{4}{|l|}{ Bacterial genera } \\
\hline $\begin{array}{l}\text { Enterobacter } \\
\text { Pseudomonas spp. } \\
\text { Acinetobacter, Pseudomonas, Massilia, Bacillus, } \\
\text { Arthrobacter, Stenotrophomonas, Ochrobactrum, and } \\
\text { Cupriavidus }\end{array}$ & $\begin{array}{l}\text { Capsicum chinense rhizosphere } \\
\text { wheat, barley, maize, oat, faba beans, peas } \\
\text { Bulk soil }\end{array}$ & $\begin{array}{l}\text { PVK } \\
\text { NBRIP } \\
\text { NBRIP }\end{array}$ & $\begin{array}{l}\text { Mendoza-Arroyo et al., } 2020 \\
\text { Elhaissoufi et al., } 2020 \\
\text { Wan et al., } 2020\end{array}$ \\
\hline Burkholderia cepaciam, B. contaminans & Sweet corn rhizosphere & PVK & Pande et al., 2020 \\
\hline \multicolumn{4}{|l|}{ Endophytes } \\
\hline Aneurinibacillus sp. and Lysinibacillus sp. & Banana tree roots & NBRIP & Matos et al., 2017 \\
\hline \multicolumn{4}{|l|}{ Nitrogen-fixing bacteria } \\
\hline Mesorhizobium spp. & Chickpea root nodules & & Muleta et al., 2021 \\
\hline Rhizobium, Agrobacterium, Phyllobacterium & Root nodules of Acacia cyanophylla & PVK & Lebrazi et al., 2020 \\
\hline Mesorhizobium ciceri, $M$. tamadayense & Cicer canariense nodules & NBRIP & Menéndez et al., 2020 \\
\hline Azotobacter & Maize rhizospheres & PVK and NBRIP & Nosrati et al., 2014; Bjelić et al., 2015 \\
\hline Azospirillum strain & Wheat rhizospheres & PVK, MPVK, and LB & Ayyaz et al., 2016 \\
\hline A. vinelandii & Soil & MPVK & El-Badry et al., 2016 \\
\hline \multicolumn{4}{|l|}{ P-solubilizing fungi (PSF) } \\
\hline $\begin{array}{l}\text { Aspergillus hydei, Gongronellahydei, P. soli, and } \\
\text { Talaromyces yunnanensis }\end{array}$ & Quercus rubra rhizosphere & PVK & Doilom et al., 2020 \\
\hline Trichoderma koningiopsis & Rice plant & NBRIP & Tandon et al., 2020; \\
\hline Penicillium guanacastense & Pinus massoniana rhizosphere & NBRIP & Qiao et al., 2019 \\
\hline \multicolumn{4}{|l|}{ Actinomycetes } \\
\hline Streptomyces roseocinereus and S. natalensis & Moroccan oat rhizosphere & MPVK & Chouyia et al., 2020 \\
\hline
\end{tabular}

NBRIP, national botanical research institute phosphate medium; PVK, Pikovskaya medium; MPVK, modified Pikovskaya medium; LB, luria bertani.

by PSM has also been unrelated (Asea et al., 1988), which suggests the involvement of mechanisms other than the OA in the $\mathrm{P}$ solubilization process which is influenced by many factors (Mohamed et al., 2018). The complex organic P compounds (phosphates, phospholipids, phytin etc.) in contrast are mineralized enzymatically by alkaline and acid phosphatases (Behera et al., 2017; Din et al., 2019), phytases (Din et al., 2019), and phospholipases (Walpola and Yoon, 2012) excreted by PSM.

\section{Mechanisms Used by PSM to Facilitate Sorghum Plant Growth}

Most of the cultivable soils in the world have insufficient elemental nutrients like $\mathrm{P}, \mathrm{N}, \mathrm{K}$, and $\mathrm{Zn}$, or these are unavailable to the plants. Also, poor agricultural practices, such as the disproportionate use of fertilizers, lead to undesirable effects such as soil fertility reduction. Indeed, a major part of chemical fertilizers applied to augment sorghum production is wasted further polluting the agroecosystem (Garnett et al., 2009). Below are some of the main mechanisms used by PSM to optimize the use of crop nutrients and help promote sorghum production.

Apart from supplying inherently $\mathrm{P}$ to plants, the P-dissolving microbiome benefits the plants by providing $\mathrm{N}$ through BNF, growth modulating enzymes, phytohormones, and antimicrobial compounds, which directly or indirectly affect the growth and development of sorghum (Table 3). The direct growth stimulation by PSM includes the acquisition of nutrients, such as $\mathrm{P}$ through solubilization/mineralization and $\mathrm{N}$ through $\mathrm{N}_{2}$ fixation, phytohormone production, and facilitation of resource while indirectly they promote growth by suppression of plant pathogens and induction of resistance in host plants against pathogens (Figure 2).
The plant growth-promoting substances released by PSM include (i) phytohormones, such as indoleacetic acid (Lebrazi et al., 2020; Qarni et al., 2021) and gibberellin (Pandya et al., 2018; Kang et al., 2019), (ii) asymbiotic (Nosrati et al., 2014; Ayyaz et al., 2016) or symbiotic $\mathrm{N}_{2}$ fixation (Muleta et al., 2021), (iii) biocontrol of phytopathogens through antifungal compounds and antibiotics (Olanrewaju and Babalola, 2019; Mitra et al., 2020) or lytic enzymes (Hamane et al., 2020; Naziya et al., 2020), and (iv) secretion of siderophores (Aallam et al., 2021) and HCN (Naziya et al., 2020; Boubekri et al., 2021). In addition to these biological enhancers, the phosphate dissolving bacteria (Kalam et al., 2020; Zhao et al., 2021), actinomycetes (Chukwuneme et al., 2020), and fungi (Ali et al., 2019) also release 1-aminocyclopropane-1-carboxylate (ACC) deaminase to protect plants from attack by pathogens. Phosphate solubilizing microbiota can also protect sorghum plants from biotic stress and stimulate growth indirectly by destructing the metabolism of attacking pathogens and/or stimulate the plant's immune system. Thus, the indirect mechanisms of PSM could be extremely useful and of great practical interest under field conditions because they provide a chance for growers to avoid the use of chemical biocides (Adesemoye and Kloepper, 2009; Khatoon et al., 2020) and, therefore, protect soils and crops from chemical toxicity.

\section{PSM-SORGHUM INTERACTIONS: INOCULATION EFFECTS ON GROWTH, CROP NUTRITION, AND GRAIN YIELD}

Application of microbes-based bio-fertilizers in agro-ecosystems is beneficial for plant growth and yield enhancement in both 

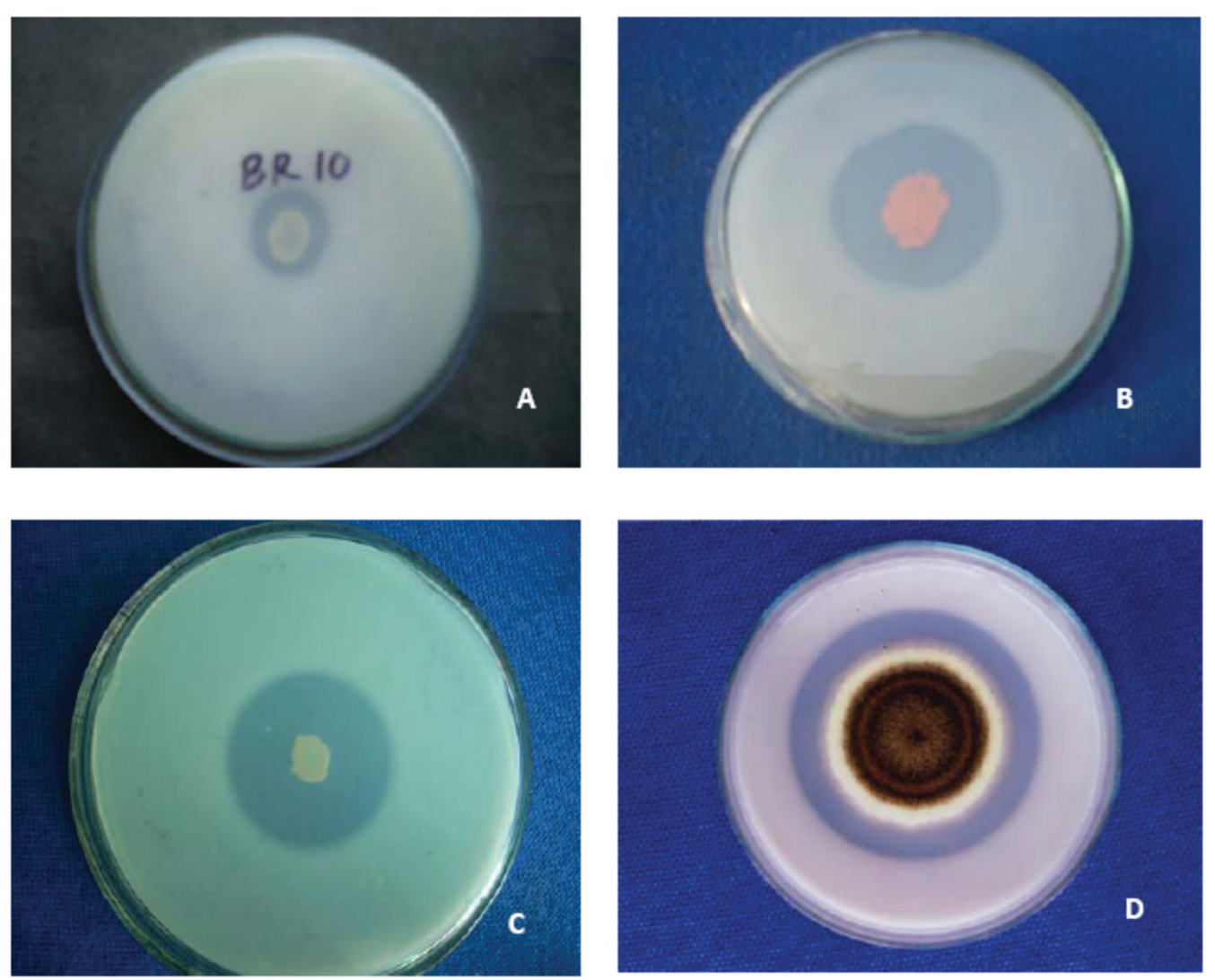

FIGURE 1 | Demonstration of solubilization of insoluble tri-calcium phosphate by species of- (A) Pseudomonas (B) Serratia (C) Bacillus and (D) Aspergillus on Pikovskaya (1948) medium.

TABLE 2 | Organic acids secreted by PSM.

PSM

Organic acids

References

\section{Phosphate solubilizing bacteria}

Bacillus, Burkholderia,

Paenibacillus sp.

Pantoea, Pseudomonas, Serratia, and Enterobacter Bacillus sp. strain AZ17

Pseudomonas sp. strain AZ5, Bacillus sp. strain

AZ17

Gluconic, oxalic, citric,

Chawngthu et al.,

tartaric, succinic, formic, and 2020

acetic acid

Oxalic, citric, gluconic

Rfaki et al., 2020

succinic, and fumaric acids

Pyruvic, succinic, fumaric,

malic, tartaric, and oxalic

acids

Acetic, oxalic and gluconic

acids, acetic, citric, and lactic acids

Phosphate solubilizing fungi

Rhizopus stolonifer and $R$.

oryzae

Oxalic, lactic, citric, succinic, Mohammed, 2020

gluconic, malic, fumaric,

acetic acid, and propionic

acids

Trichoderma and Aspergillus Oxalic, citric, formic, tartaric, malic, acetic, and citric acids

Penicillium oxalicum and $A$.

Gluconic acid, oxalic,

Li et al., 2016

propionic, and malic acids

\section{Phosphate solubilizing actinomycetes}

Streptomyces sp.

Gluconic acid

Zúñiga-Silgado

et al., 2020

Zaheer et al., 2019

KP109810, Streptomyces

sp. CTM396 conventional (Kalayu, 2019) and extreme environments (Kamali and Mehraban, 2020; Rizvi et al., 2020). Among microbial formulations, the research on PSMs impacting growth, crop nutrition, and yield of cereal crops under greenhouse/field trials are quite large (Table 4). The literature regarding PSM application in sorghum cultivation systems in different agroecological regions is, however, lacking. Considering this gap, the beneficial influence of PSM including PS bacteria (PSB), fungi (PSF), and actinomycetes (PSA) used either alone or in combination with other conventional PGPR or arbuscular mycorrhizal (AM) fungi is highlighted. A model explaining the ameliorative impact of the PSM on morphological, cellular, and physiological activities of the sorghum plant is presented in Figure 3.

\section{Inoculation Effects of Single PSM}

The inoculation of the P-solubilizing microbiome is considered a promising and inexpensive microbiological option, not to mention the most sustainable one, in food production systems because it increases the $\mathrm{P}$ bioavailability without destructing the soil-plant systems. Sorghum, considered a substitute to rice, adapts well to $\mathrm{P}$ deficient soils employing absorption and solubilization mechanisms including interaction with PSM. The direct application of RP either alone or/and followed by the inoculation of the PSM is however, a suitable alternative to 
TABLE 3 | Plant-growth-promoting active biomolecules released by PSM.

\begin{tabular}{|c|c|c|c|}
\hline Soil microbiome & Source & PGP activities & References \\
\hline Mesorhizobium spp. & Chickpea root nodules & IAA, ACC deaminase, siderophores, $\mathrm{HCN}$ & Muleta et al., 2021 \\
\hline $\begin{array}{l}\text { Streptomyces alboviridis P18-S. } \\
\text { griseorubens BC3-S. griseorubens BC10 } \\
\text { and Nocardiopsis alba BC11 }\end{array}$ & Desert soils of Morocco & IAA, siderophore, $\mathrm{HCN}$, and ammonia & Boubekri et al., 2021 \\
\hline $\begin{array}{l}\text { Staphylococcus sp., Bacillus firmus, B. } \\
\text { safensis, and B. licheniformis }\end{array}$ & Soils of rock $P$ mines & IAA, ACC Deaminase & Qarni et al., 2021 \\
\hline Penicillium sp. and Penicillium oxalicum & Soils of rock $\mathrm{P}$ mines & IAA & Qarni et al., 2021 \\
\hline Burkholderia ubonensis & $\begin{array}{l}\text { Woodland soil of a Chinese fir } \\
\text { plantation }\end{array}$ & IAA, ACC deaminase, nitrogenase, iron carriers & Zhao et al., 2021 \\
\hline Streptomyces roseocinereus MS1B15 & Moroccan oat rhizosphere & $\begin{array}{l}\text { IAA, Siderophores, ACC deaminase, } \mathrm{N}_{2} \text { fixation, } \\
\text { antimicrobial activity }\end{array}$ & Chouyia et al., 2020 \\
\hline Bacillus strains & $\begin{array}{l}\text { Rhizosphere, leaf endosphere, and } \\
\text { sap of P-efficient tropical maize } \\
\text { genotypes }\end{array}$ & IAA & de Sousa et al., 2021 \\
\hline $\begin{array}{l}\text { Agrobacterium tumefaciens syn. } \\
\text { Rhizobium radiobacter }\end{array}$ & Nodules of Leucaena leucocephala & $\begin{array}{l}\text { Zinc solubilization, IAA, } N_{2} \text { fixation, siderophores, } \\
\text { EPS, salt tolerance }\end{array}$ & Verma et al., 2020 \\
\hline S. roseocinereus, S. natalensis & Oat rhizospheres & $\begin{array}{l}\text { Siderophores, IAA, ACC deaminase, antimicrobial } \\
\text { activity against Fusarium oxysporum, Botrytis cinerea, } \\
\text { Phytophthora cactorum, and Phytophthora cryptogea }\end{array}$ & Chouyia et al., 2020 \\
\hline $\begin{array}{l}\text { Agrobacterium sp. NA11001, } \\
\text { Phyllobacterium sp. C65, Bacillus sp. } \\
\text { CS14, and Rhizobium sp. V3E1. }\end{array}$ & Root nodules of Acacia cyanophylla & IAA & Lebrazi et al., 2020 \\
\hline $\begin{array}{l}\text { Alternaria, Aspergillus, Chaetomium, } \\
\text { Curvularia, Fusarium, Melanaspora, } \\
\text { Nigrospora, Penicillium and Trichoderma }\end{array}$ & Chilli rhizosphere & IAA, siderophores, $\mathrm{HCN}$, chitinase & Naziya et al., 2020 \\
\hline Acinetobacter sp., PGP27, Ensifer meliloti & Faba bean and wheat rhizosphere & K solubilization, IAA, EPS & Bechtaoui et al., 2019 \\
\hline Bacillus sp. & Stevia rebaudiana rhizosphere & IAA, siderophores & Prakash and Arora, 2019 \\
\hline $\begin{array}{l}\text { Lysinibacillus fusiformis, Bacillus sp., } \\
\text { Paenibacillus sp. }\end{array}$ & Roots of wheat & $\begin{array}{l}\text { IAA, siderophore production, protease activity, } \\
\text { antibacterial and antifungal inhibition }\end{array}$ & Akinrinlola et al., 2018 \\
\hline $\begin{array}{l}\text { Mesorhizobium ciceri and } M \text {. } \\
\text { mediterraneum }\end{array}$ & Chickpea nodules & $\mathrm{N}_{2}$ fixation, IAA & Zafar et al., 2017 \\
\hline $\begin{array}{l}\text { Klebsiella sp. Br1, K. pneumoniae Fr1, B. } \\
\text { pumilus S1r1, Acinetobacter sp. S3r2 }\end{array}$ & Maize roots & $\mathrm{N}_{2}$ fixation, auxin production & Kuan et al., 2016 \\
\hline Mucror, Penicillium & Panax ginseng rhizosphere & IAA & Hussein and Joo, 2015 \\
\hline
\end{tabular}

supply $\mathrm{P}$ to the growing sorghum crops. Recently (Mattos et al., 2020), evaluated the effect of PSB inoculation on two sorghum genotypes (BR007-efficient and responsive and SC283efficient and non-responsive) with different $\mathrm{P}$ sources (RP and triple superphosphate, TSP). The sorghum genotypes were inoculated separately with the PSB Bacillus strains (B116 and B70) and were cultivated in greenhouse and field soils fertilized with TSP, RP, $1 / 2 \mathrm{TSP}+1 / 2 \mathrm{RP}$. The PSB inoculation significantly increased the root biomass and $\mathrm{P}$ content under greenhouse and grain yield and grain P content of genotype BR007 grown in the field but had no effect on genotype SC283. The application of PSB as P-bioinoculant with RP acted as a promising alternative to reduce the use of synthetic chemical fertilizers leading to sustainable production of sorghum. The findings of this experiment, however, suggested that the impact of PSB inoculation varied according to (i) sorghum genotype, (ii) $\mathrm{P}$ source, and (iii) phosphobacterial strains. A field experiment by (Shete et al., 2018) conducted for three consecutive rabi seasons applying a drought-tolerant PSB strain with or without $\mathrm{N}$ and $\mathrm{P}$ sources showed a variable effect on the growth and yield of rabi sorghum. The sorghum seed inoculated with PSB strain (Acc. No.1/2012) and $100 \%$ recommended $\mathrm{N}$ and $75 \%$ recommended $\mathrm{P}_{2} \mathrm{O}_{5}$ demonstrated the highest plant height $(199.9 \mathrm{~cm})$, grain yield $(18.13 \mathrm{q} / \mathrm{ha})$, stover yield $(62.96 \mathrm{q} / \mathrm{ha})$,
1,000 grain weight $(28.86 \mathrm{~g}), \mathrm{P}$ uptake $(14.14 \mathrm{~kg} / \mathrm{ha})$, benefit: cost ratio (3.17) and PSB counts $\left(4.67 \times 10^{4}\right)$ at flowering stage. The results firmly indicate a saving of $25 \%$ of chemical $\mathrm{P}$ fertilizer for rabi sorghum under dryland conditions. Seed inoculation with Pseudomonas putida strain 168 in other experiments resulted in the highest dried forage, maximum dry matter digestibility, and crude protein while $P$. putida strain 41 produced maximum water-soluble carbohydrates. Seed inoculation with bacterial strains alone (especially strain 168) increased nutrient uptake, plant growth and consequently enhanced the yield. Among the PSB strains, P. putida strain 168 was superior compared even to dual culture application suggesting the antagonism between the two PSB strains (Ehteshami et al., 2014). In a similar investigation, the PSB significantly increased the shoot growth, ear head weight, and $\mathrm{P}$ content in both roots and shoots, and the grain yield of sorghum rose under a greenhouse environment, compared to plants grown without bacterial cultures and treated with RP and single superphosphate (Vikram, 2007). The inoculation of PSF, Aspergillus terreus, and Penicillium pinophilum in association with the reactive phosphate rock (RPR) improved the shoot growth, P-uptake, and enhanced the dry matter yield of sorghum, when grown under greenhouse conditions. The PSF application increased the shoot dry matter yield by $30 \%$ while the plant 


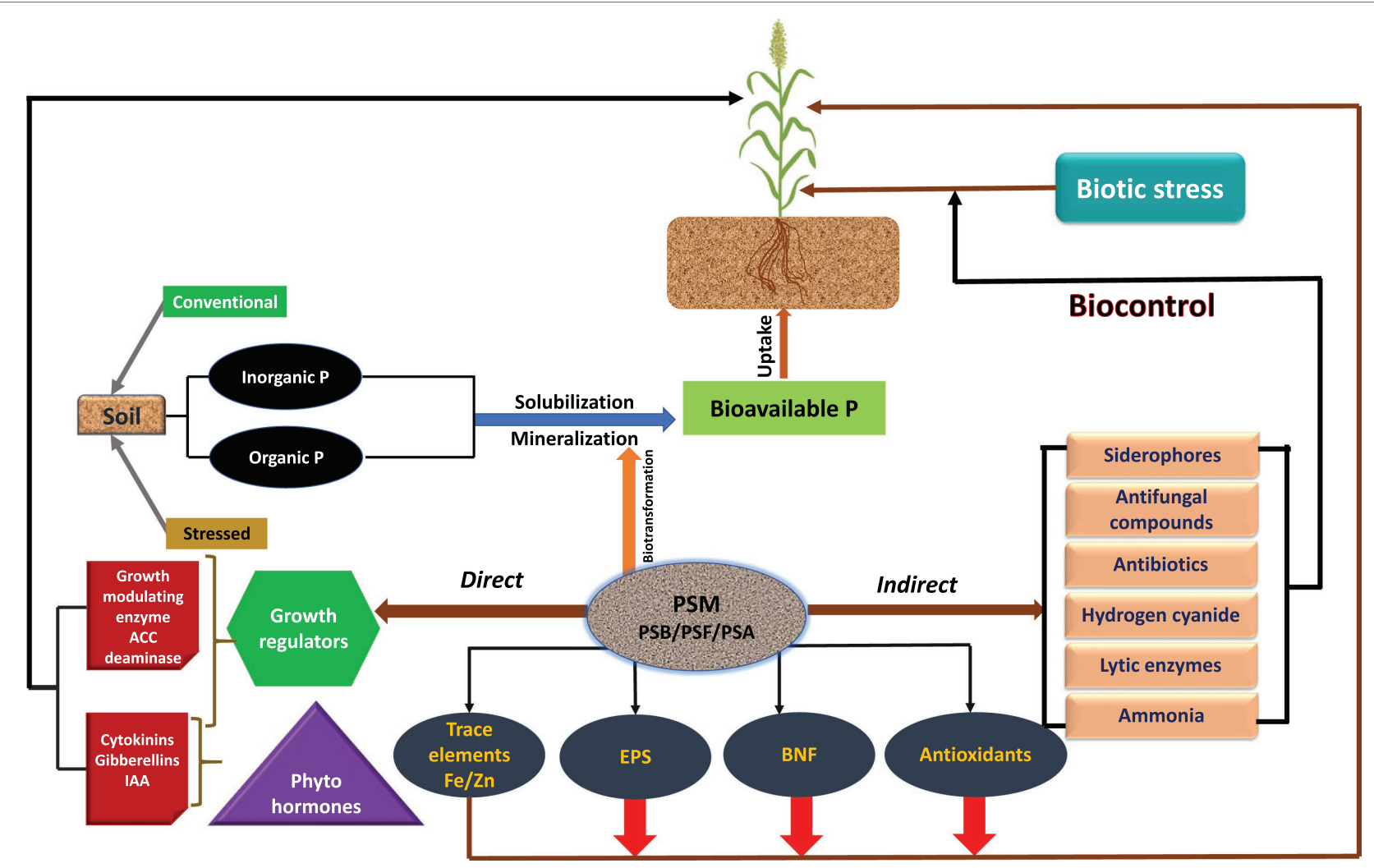

FIGURE 2 | Mechanism used by phosphate solubilizing microbiome (PSM) to facilitate sorghum plant growth.

height was enhanced by $42 \%$ compared to the uninoculated plants. The PSF inoculation, however, did not affect the root growth of sorghum plants. Moreover, the PSF substantially increased the P concentration by 61 and $71 \%$ in the absence and presence of RPR and 110 and $265 \%$ in the P accumulation of sorghum relative to the control, respectively. The PSF application, therefore, showed a more obvious beneficial impact on organ growth and sorghum P uptake (Steiner et al., 2016). A study conducted by Srinivasan et al. (2012) revealed that PSB identified using BIOLOG belonging to Pseudomonas, Xanthomonas, Bacillus, Aerococcus, Alteromonas, Erwinia, and Enterobacter while PSF identified as Aspergillus and Penicillium produced IAA and gibberellic acid (GA). The IAA produced by the bacterial cultures ranged between 0.74 and $9.53 \mu \mathrm{g} 25 \mathrm{ml}^{-1}$ while GA varied between 2.08 and $12.55 \mu \mathrm{g} 25 \mathrm{ml}^{-1}$. The amount of IAA secreted by the PSF differed from 2.33 to $8.69 \mu \mathrm{g} 25 \mathrm{ml}^{-1}$ and GA ranged from 3.44 to $14.80 \mu \mathrm{g} 25 \mathrm{ml}^{-1}$. Among the two P-solubilizers, PSF was superior to PSB in terms of P solubilization and increased maximally the stem girth, root length, root dry matter, and total dry matter of sorghum plants.

\section{Inoculative Synergism Between PSM, $\mathrm{N}_{2}$ Fixers, and AM-Fungi}

The impact of mixed formulations of bio-enhancers belonging to two or more physiologically related/divergent groups has generally been excellent in promoting crop performance compared to single or mono culture applications
(Keller-Pearson et al., 2020; Dierks et al., 2021; Nogales et al., 2021). During composite application, the synergistic or additive effect of the interacting microbe is expected on growth, crop nutrition, and yield of crops. For example, bio-fertilizer organisms can improve the growth of a plant independently through $\mathrm{N}_{2}$ fixation or through the production of growth hormones or synergistically through both mechanisms simultaneously. Therefore, a synergistic relationship promotes the growth, crop nutrition, and yield of plants more efficiently than solo culture because the microbial pairing allows the plants to achieve greater absorption of minerals (NPK) and other elements. However, little is known about the synergistic effect of PSM and other PGPR or AM-fungi on sorghum (Cobb et al., 2016). The combined effect of two or more PSM together or PSM with $\mathrm{N}_{2}$ fixers or AM fungi on sorghum is reviewed and highlighted.

\section{Composite Application of Phosphate Solubilizers}

Some recent data by Rezakhani et al. (2020) indicate that the single-and dual cultures of PSB, Pseudomonas sp. FA1, and Bacillus simplex UT1 and different concentrations of silicon had variable impact on the morphological, nutritional uptake of P, Si and K, and physiological activities of Sorghum bicolor plant fertilized with soluble or insoluble P (RP; Rezakhani et al., 2020). In this sense, the RP-fertilized sorghum had better root and shoot biomass while the PSB strains and Si levels applied independently augmented all the measured bio-chemical 
TABLE 4 | Inoculation effects of PSM on the performance of cereal crops grown in different agroecological systems.

\begin{tabular}{|c|c|c|c|}
\hline PSM inoculants & Growth parameters of cereals & Experimental conditions & References \\
\hline \multicolumn{4}{|l|}{ Sorghum } \\
\hline $\begin{array}{l}\text { Bacillus simplex and Pseudomonas sp. } \\
\text { Aspergillus terreus and Penicillium } \\
\text { pinophilum }\end{array}$ & $\begin{array}{l}\text { Growth, plant dry matter, and P use efficiency } \\
\text { P uptake and dry matter yield }\end{array}$ & $\begin{array}{l}\text { Greenhouse } \\
\text { Greenhouse }\end{array}$ & $\begin{array}{l}\text { Rezakhani et al., } 2020 \\
\text { Steiner et al., } 2016\end{array}$ \\
\hline Streptomyces sp. & Growth and yield enhancement & Field & Alekhya and Gopalakrishnan, 2016 \\
\hline \multicolumn{4}{|l|}{ Maize } \\
\hline $\begin{array}{l}\text { Azospirillum brasilense, B. subtilis, } \\
\text { P. fluorescens }\end{array}$ & Improved P uptake efficiency and greater yield & Greenhouse & Pereira et al., 2020 \\
\hline $\begin{array}{l}\text { Achromobacter xylooxidans, Leclerciaa } \\
\text { decarboxylata }\end{array}$ & $\begin{array}{l}\text { Increased photosynthetic rate, stomatal } \\
\text { conductance, chlorophyll, carotenoids, and grain } \\
\text { yield }\end{array}$ & Greenhouse & Danish et al., 2020 \\
\hline B. subtilis & Increased productivity and shoots $P$ & Field & Lobo et al., 2019 \\
\hline Aspergillus flavus & Growth and mineral contents & Greenhouse & Omomowo et al., 2020 \\
\hline Streptomyces sp. KP109810 & $\begin{array}{l}\text { Efficient promotion of maize growth and } \mathrm{P} \\
\text { content }\end{array}$ & Greenhouse & Mohammed, 2020 \\
\hline \multicolumn{4}{|c|}{ 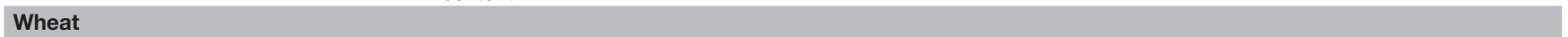 } \\
\hline Streptomyces alboviridis P18- & Improved root length, root volume, root dry & & Boubekri et al., 2021 \\
\hline S. griseorubens BC3- & weight, shoot length, and shoot dry weight & & \\
\hline \multicolumn{4}{|l|}{$\begin{array}{l}\text { S. griseorubens } \mathrm{BC} 10 \text { and Nocardiopsis } \\
\text { alba } \mathrm{BC} 11\end{array}$} \\
\hline Paenibacillus sp. & $\begin{array}{l}\text { Significantly increased the plant height, biomass, } \\
\text { root growth, and } \mathrm{P} \text { uptake }\end{array}$ & & Chen and Liu, 2019 \\
\hline Streptomyces & $\begin{array}{l}\text { Plant height, root and shoot dry matter and p } \\
\text { uptake }\end{array}$ & Greenhouse & El-Dsouky et al., 2019 \\
\hline \multicolumn{4}{|l|}{ Rice } \\
\hline Pantoea sp. & $\begin{array}{l}\text { Significantly increased the plant height, biomass, } \\
\text { root growth, and P uptake }\end{array}$ & Field & Chen and Liu, 2019 \\
\hline Aspergillus niger & Increased grain yield & Field & $\begin{array}{l}\text { Asuming-Brempong and Anipa, } \\
2014\end{array}$ \\
\hline Streptomyces KT 6-4-1 & Increased root length, plant height, and dry mass & Greenhouse & Chaiharn et al., 2018 \\
\hline \multicolumn{4}{|l|}{ Millet } \\
\hline Bacillus strains & $\begin{array}{l}\text { Enhanced biomass production and accumulation } \\
\text { of N P K in the shoot }\end{array}$ & Greenhouse & Ribeiro et al., 2018 \\
\hline Bacillus sp. (C2) and Pseudomonas sp. & $\begin{array}{l}\text { Increased height, total chlorophyll, IAA, starch, } \\
\text { fresh and dry weight }\end{array}$ & & Harinathan et al., 2016 \\
\hline \multicolumn{4}{|l|}{ Barley } \\
\hline Streptomyces roseocinereus MS1B15 & Plant growth and $\mathrm{P}$ uptake & Greenhouse & Chouyia et al., 2020 \\
\hline
\end{tabular}

properties. Application of Pseudomonas sp. FA1 and B. simplex UT1 and Si with soluble P or insoluble P significantly enhanced P-use efficiency of sorghum plants. As a co-culture, both B. simplex and Pseudomonas sp. considerably increased the dry matter and $\mathrm{P}$ uptake of sorghum plants when raised with both forms of $\mathrm{P}$ fertilizer. While comparing the inoculation effects of the two PSB, Pseudomonas sp. was more efficacious than B. simplex. The composite culture of PSB with Si had the largest increase in $\mathrm{P}$ uptake and other growth indices. The results clearly suggest that the co-application of PSB and $\mathrm{Si}$ along with RP fertilization may serve as a substitute for chemical $\mathrm{P}$ fertilizer in sustainable sorghum cultivation practices. Studies by (Jisha and Alagawadi, 1996) revealed a variable impact of dual inoculation of PSB bacteria, $P$. striata, or B. polymyxa with the cellulolytic fungus, Trichoderma harzianum, on the nutrient uptake and yield of Sorghum grown in a vertisol treated with cotton stalks. Composite application of B. polymyxa or $P$. striata with $T$. harzianum increased the size and weight of the earhead, the number of spikelets per ear, and the straw and grain yield, and $\mathrm{N}$ and $\mathrm{P}$ uptake significantly relative to uninoculated control and single PSB application. Grain yield was increased by $6-8 \%$ due to co-inoculation over mono P-solubilizers inoculation and by $28-30 \%$ over T. harzianum alone.

\section{Synergism Between PSM and $\mathrm{N}_{2}$ Fixers}

Among phytonutrients, $\mathrm{N}$ and $\mathrm{P}$ are the two major nutrients that affect many important cellular processes like root elongation, proliferation and changes of root architecture, seed development, and maturity of plants growing both under conventional and stressful conditions (Liu et al., 2020; Patel and Panchal, 2020). The combined inoculation of PSM and $\mathrm{N}_{2}$ fixers benefit plants better than either group of organisms used alone while substantially reducing the application of chemical fertilizers under field conditions (Gheliya et al., 2018; Li et al., 2020). Considering this (Afifi et al., 2014), in a field experiment conducted at Ismailia Agricultural Research Station, Agriculture Research Centre (ARC), Egypt, evaluated the impact of an associative $\mathrm{N}_{2}$ fixer, Azospirillum brasilense, PSB B. megaterium, and potassium solubilizing bacterium (KSB) B. circulans, applied either alone or in combined forms and treated individually 


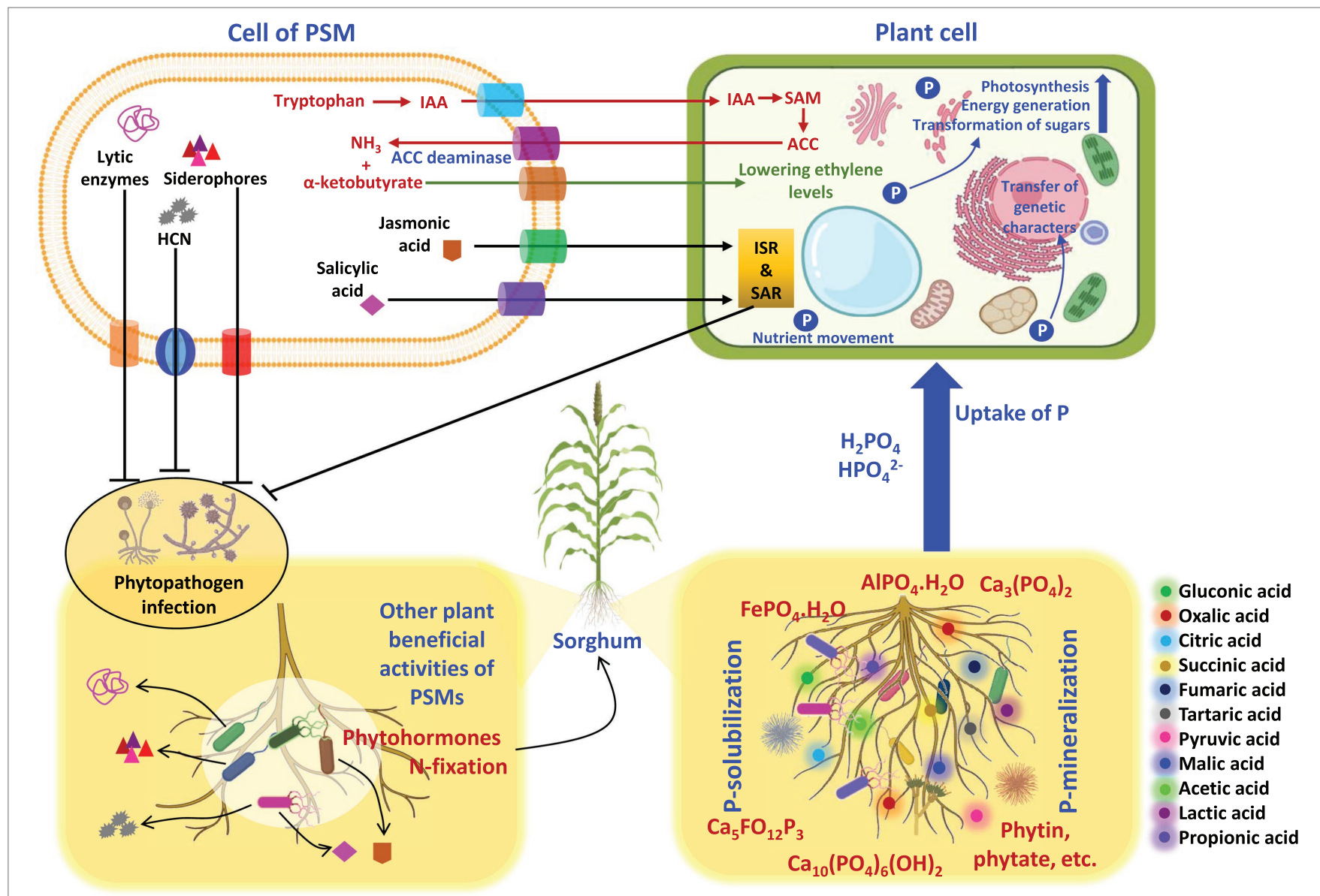

FIGURE 3 | Interactions of PSM with sorghum plants at cellular levels enhancing the growth of sorghum. HCN, hydrogen cyanide; IAA, indole-3-acetic acid; ACC, 1-aminocyclopropane-1-carboxylic acid; SAM, S-adenosyl methionine; ISR, induce systemic resistance; SAR, systemic acquired resistance.

with either humic or fulvic acids, on the availability of $\mathrm{N}, \mathrm{P}$, and $\mathrm{K}$ and their overall impact on morphology, physiology, and the yield attributes of S. bicolor (cv. Dorado) in the presence of $50 \%$ of the recommended dose of mineral NPK. Half of the recommended dose $(175 \mathrm{~kg} / \mathrm{fed})$ of ammonium sulfate $(20.5 \%)$ was added during sowing and 30 and 60 days after sowing with A. brasilense only. Half of the recommended dose of $\mathrm{P}$ $(100 \mathrm{~kg} / \mathrm{fed})$ as super phosphate $\left(15.5 \% \mathrm{P}_{2} \mathrm{O}_{5}\right)$ was applied during soil preparation containing $B$. megaterium only, while half of the recommended dose $(25 \mathrm{~kg} / \mathrm{fed})$ of potassium sulfate $(48 \%$ $\mathrm{K}_{2} \mathrm{O}$ ) was applied once only at 60 days before the earing stage inoculated with $B$. circulans only. The application of bacterial cultures either alone or as a mixture was more effective and maximally enhanced the growth and the yield of sorghum plants. Among all formulations, the mixture of bacterial cultures and humic acid demonstrated the highest populations of bacterial group in the sorghum rhizosphere. Biological features such as plant height, plant dry weight, and number of branches and biochemical attributes like nitrogenase, dehydrogenase, and phosphatase activities were significantly increased in the presence of co-culture of $A$. brasilense, B. megaterium, and B. circulans plus humic acid after 45 and 75 days of sorghum growth.
Also, the NPK, crude protein, and total carbohydrates (\%) were at maximum in sorghum grains. The A. brasilense, B. megaterium, and $B$. circulans when used together exhibited the highest grains yield (3.55 ton/fed) and 1,000 grains weight over control (full NPK). The findings clearly revealed that each bacterial stain could reduce the half doses of NPK through P and K solubilization and $\mathrm{N}$-fixation processes. In a similar recent study, the impact of the asymbiotic nitrogen fixer (A. chroococcum) and P solubilizer (B. megaterium) on growth, yield parameters, and nutrient uptake of Sorghum bicolor grown under greenhouse conditions varied considerably (Vijayalakshmi et al., 2020). The formulations consisting of $A$. chroococcum and B. megaterium magnified the microbial populations in soil and through synergistic interaction increased the bioavailability of $\mathrm{N}$ and $\mathrm{P}$ and some other nutrients in the soil during sorghum harvest. The dual culture of $\mathrm{N}_{2}$ fixer and $\mathrm{P}$ solubilizer applied with a $100 \%$ recommended dose of fertilizer (RDF) had a maximum beneficial impact on growth (plant height, length, and dry weight of root and shoot), nutrient uptake (NPK), and grain yield of sorghum compared to the uninoculated plants at harvest. The maximum number of grains (190/plant) and grain weight (5.23 g/plant) were observed with $100 \% \mathrm{RDF}$ and combined formulations of Azotobacter with 
PSB, which was followed by the $75 \%$ RDF with Azotobacter and PSB. A profound increase in the yield of sorghum was attributed as being largely due to the supply of $\mathrm{N}$ and $\mathrm{P}$ by the $\mathrm{N}_{2}$ fixer and PSB to sorghum crops. This increase was well supported by enhancement in N (highest N 1.9\%) and P (highest $\mathrm{P}$ uptake $0.41 \%$ ) uptake by sorghum plants due to inoculation of Azotobacter with PSB along with $100 \%$ RDF at harvest compared to uninoculated and unfertilized control plants. In a similar greenhouse experiment (Alagawadi and Gaur, 1988, 1992), observed a significant increase in the yield of sorghum due to combined inoculation of PSB, $P$. striata or B. polymyxa and $\mathrm{N}_{2}$ fixing $A$. brasilense which indicated a positive interaction between the dissimilar groups of bacteria. The yields were, however, markedly further enhanced by the application of $40 \mathrm{kgN}$ as urea and $60 \mathrm{~kg} \mathrm{P}_{2} \mathrm{O}_{5}$ (rock phosphate) per ha along with bacterial cultures over sole application of fertilizer or only bacterial inoculation. Due to this, it was suggested that $40 \mathrm{kgN}$ could be saved and the whole quantity of super phosphate could be replaced by RP plus inoculation of $A$. brasilense and P. striata or B. polymyxa. The population counts of Azospirillum and phosphate-solubilizing bacteria in the rhizosphere of sorghum were higher in the respective inoculation treatments than in uninoculated treatments.

\section{Synergism Between PSM and AM-Fungi}

The AM-fungi during interaction receive sugars, amino acids, vitamins, and other organic substances from the host plant. In return, it absorbs minerals, especially $\mathrm{P}$ from the soil, and enhances the growth and yield of the host plant (Johansson et al., 2004). Agronomically, when the two dissimilar groups of beneficial organisms are applied in crop cultivation, the yield of many crops increases substantially (Saxena et al., 2013; Nacoon et al., 2020). Like other PGPR, AM- fungi and PSB interact synergistically wherein PSB solubilize sparingly available $\mathrm{P}$ compounds into orthophosphate that AM-fungi absorbs and transport to the host plants (Ordoñez et al., 2016). The reports on the inoculation effects of single or multiple PGPR on many cereal crops are numerous (Wahid et al., 2016; Naseri et al., 2018), but there is a scarcity of information on the synergistic effect of the PSM and AM-fungi on sorghum plants. Below, the role of composite application of PSM and AM fungi in the growth and yield promotion is highlighted.

Principally, AM-fungi provide nutrients to their host plants by producing hyphae that grow out from plant roots, effectively increasing the soil volume from which immobile nutrients can be acquired. So, mycorrhizal agricultural crops perform better and can be more productive compared with non-mycorrhizal plants. In addition, AM-fungi increase and improve the amounts of secondary compounds in plants (Mohamed et al., 2014). The synergy between AM-fungi and PSB with NPK fertilizer demonstrated variable growth and yield impact on greenhousegrown sweet sorghum under saline conditions (Ramadhani and Widawati, 2020). The dual inoculation of AM-fungi and PSB in the presence of varying doses of NPK increased the plant height, the number of leaves, plant fresh weight, plant dry weight, and $\mathrm{P}$ of sweet sorghum plant. The AM-fungi and PSB applied with 25\% NPK produced the highest increase in all the biological features of sorghum plants, suggesting that the colonization between AM-fungi and PSB with NPK fertilizer could be a suitable and economical option for enhancing sorghum production even under saline conditions. The results of a study conducted by (Ziaeyan et al., 2016) showed that the plants inoculated with a combination of PSB and AM-fungi expressed synergistic effect to increase the efficiency of $\mathrm{P}$ fertilizer and growing conditions and yield of sorghum. The combined application of $25 \mathrm{mg} \mathrm{P}_{2} \mathrm{O}_{5}$ per $\mathrm{kg}$ of soil along with the PSB and AM-fungi maximally enhanced the biological attributes and therefore, could be recommended to save the $\mathrm{P}$ application in sorghum cultivation systems. Nitroxin, a bio-fertilizer prepared from a mixture of asymbiotic $\mathrm{N}_{2}$ fixers Azospirillum and Azotobacter and AM-fungus (Glomus mosseae), mitigated the deleterious effects of stress by increasing the amounts of photosynthetic pigments, soluble proteins and osmotic regulation and decreasing electrolyte leakage in sorghum and, hence, increased the yield significantly. Mechanistically, the interacting bacterial genera had $\mathrm{N}_{2}$ fixation, $\mathrm{P}$ solubilization, and iron releasing abilities, as well as the capability to secret plant hormones such as auxin, cytokinin, and gibberellin and a growth modulating enzyme, ACC-deaminase, which together enhanced the yield substantially (Olanrewaju et al., 2017).

The interactions between PSM, $\mathrm{N}_{2}$ fixers, and AM-fungi in terms of facilitating plant growth, nutrient uptake, and yield have been reported in numerous studies in the literature. The information regarding the inoculative effect of PSM, $\mathrm{N}_{2}$ fixers AM fungi on sorghum is scanty. Widada et al. (2007) demonstrated that sorghum plants inoculated with PSB (Pseudomonas sp.), $\mathrm{N}_{2}$ fixer (Azospirillum lipoferum), and AM-fungi (Glomus manihotis and Entrophospora colombiana) and grown in acid and $\mathrm{P}$ deficient soils improved the plant dry weight and nutrients (such as $\mathrm{N}, \mathrm{P}, \mathrm{Fe}$, and $\mathrm{Zn}$ ) uptake, which were enhanced further by dual inoculation of selected microbiome compared to the single inoculation. Dual inoculation of AM-fungi with PSB and AM-fungi and $\mathrm{N}_{2}$ fixer increased plant dry weight by 112 and 64 times compared to the uninoculated plant, respectively. The selected rhizobacteria also improved plant colonization by AM-fungi. These results suggest that the tripartite interaction between PSB, $\mathrm{N}_{2}$ fixer, and AM-fungi can be an excellent strategy for optimizing sorghum production since no antagonisms among interacting organisms were observed.

\section{BIOTIC STRESS ALLEVIATION BY PSM}

Pathogenic microorganisms are a major and continuing threat to food production and ecosystem stability worldwide. Yield, grain quality, and production stability of sorghum are constrained by various biotic (Kumar and Ram, 2014) and abiotic (Tari et al., 2013) stressors, resulting in poor marketability and utilization and causing severe economic losses. Among biotic factors, numerous fungal and bacterial diseases (Table 5) are of prime concern in sorghum-producing areas across the world. Attempts have been made to reduce pesticide use, develop stress-resistant varieties, enhance ecological fitness, and create 
TABLE 5 | An overview of various diseases caused in sorghum following biotic stress.

\begin{tabular}{|c|c|c|c|c|}
\hline Diseases & Causal organism & Major organs affected & Hotspot locations & References \\
\hline \multicolumn{5}{|l|}{ Bacterial diseases } \\
\hline Bacterial leaf streak & $\begin{array}{l}\text { Xanthomonas campestris pv. } \\
\text { Holcicola }\end{array}$ & Leaves & Wide geographical distribution & Wang et al., 2021 \\
\hline Bacterial leaf stripe & Burkholderia andropogonis & $\begin{array}{l}\text { Leaves, flower buds, } \\
\text { peduncles }\end{array}$ & Semi-arid and tropical regions & Mareya et al., 2020 \\
\hline Bacterial leaf spot & Pseudomonas syringae & Leaves & $\begin{array}{l}\text { Argentina, Bulgaria, China, Hungary, India, } \\
\text { Italy, Mexico, Africa, Rumania, Yugoslavia, } \\
\text { Venezuela }\end{array}$ & Hernandez et al., 1992 \\
\hline \multicolumn{5}{|l|}{ Fungal diseases } \\
\hline Anthracnose & Colletotrichum sublineolum & All above-ground parts & United States, India, Mexico, Nigeria & Abreha et al., 2021 \\
\hline Charcoal rot & $\begin{array}{l}\text { Macrophomina phaseolina } \\
\text { (Tassi) Goid }\end{array}$ & Root and stalk & India, Africa, Australia, United States & Mahmoud et al., 2018 \\
\hline Downy mildew & Peronosclerospora sorghi & Seedling and leaves & Africa, Asia, Mexico, America & Prom et al., 2015 \\
\hline Covered kernel smut & Sporisorium sorghi & Kernels & Ethiopia, Africa & Nigusie and Ademe, 2020 \\
\hline Head smut & Sporisorium holci-sorghi & Panicle & $\begin{array}{l}\text { Africa, Europe, North and South America, } \\
\text { Mexico, Asia, Australia, New Zealand }\end{array}$ & Wagari, 2019 \\
\hline Loose kernel smut & Sporisorium cruentum & Kernels and panicles & Egypt & Moharam, 2018 \\
\hline Rust & Puccinia purpurea & Leaves & Nigeria, India, Mexico, United States & Wang et al., 2014 \\
\hline Rough leaf spot & Ascochyta sorghi & Leaves & China & Xu et al., 2019 \\
\hline Leaf blight & Helminthosporium turcicum & Leaves & $\begin{array}{l}\text { Mexico, Brazil, India, Sudan, Nigeria, } \\
\text { Niger, Kenya, and Ethiopia }\end{array}$ & $\begin{array}{l}\text { Das and Rajendrakumar, } \\
2016\end{array}$ \\
\hline Ergot & Claviceps sorghi & Spikelets & Israel & Shimshoni et al., 2017 \\
\hline Pokkah Boeng (twisted top) & Fusarium subglutinans & Leaf and top & India & Das et al., 2019 \\
\hline Zonate leaf spot & Gloeocercospora sorghi & Leaves & China & Jiang et al., 2018 \\
\hline Sooty stripe & Ramulispora sorghi & Leaves & United States & Brady et al., 2011 \\
\hline Grain mold & Aspergillus sp., Penicillium sp. & Grains & Asia and Africa & Das et al., 2020 \\
\hline Target leaf spot & Bipolaris sorghicola & Leaves & United States, India, Japan & Kimball et al., 2019 \\
\hline
\end{tabular}

a sustainable production system in order to enhance efficiency, grain quality, and profitability (Sharma, 1985; Kumar et al., 2014). None of these approaches have, however, been completely successful due to several reasons such as the production cost, lethal impacts of agrochemicals, emergence of resistance among pathogens toward one or multiple biocides/pesticides, and lack of genetic resistance to sorghum varieties. These factors have generated interest among sorghum growers in employing biotechnological options, including the use of inexpensive PSM in the management of sorghum phytopathogens (Khasa, 2017; Nepomuceno et al., 2019; Mitra et al., 2020). The application of PSM in the abatement of phytopathogens has certain advantages, such as (i) not causing environmental hazards; (ii) precluding residual toxicity; and (iii) blocking the emergence of resistance among pathogens attacking sorghum. PSM controls the pathogen damage by one or simultaneous mechanisms through biocide compounds and optimizes the yields (Zaidi et al., 2014; Choudhary et al., 2016). The literature on the role of PSM in the management of phytopathogens affecting sorghum is, however, without doubt, lacking.

\section{Mechanism of Disease Suppression}

The PSM controls the phytopathogens attack by synthesizing pivotal molecules like siderophores (Sarr et al., 2020), antibiotics (Raaijmakers and Mazzola, 2012), lytic enzymes (Herrera-Quiterio et al., 2020), cyanogenic compounds (Munir et al., 2019), and through induction of systemic resistance (ISR; Audenaert et al., 2002). Due to this, the soil PSM improves the growth and grain yield of sorghum by suppressing the damaging impact of biotic stresses. Below are some of the main mechanisms employed by PSM to manage phytopathogens and to boost sorghum yields.

\section{Siderophores}

Under iron-starved conditions, numerous PSMs, including bacteria, fungi, and actinomycetes, produce a wide range of siderophores (Maldonado et al., 2020; Aallam et al., 2021) with relatively low molecular weight (below $\approx 2 \mathrm{kDa}$ ) and ferric ion-specific chelating agents at neutral to alkaline $\mathrm{pH}$ to solubilize, capture, and transport inorganic iron to cell (Sandy and Butler, 2009). They are, therefore, exploited in the management of plant diseases (Verma et al., 2011; Jyothi et al., 2020). The siderophore positive rhizobacteria protect the plants from damages by preventing the iron acquisition (Estrella and Chet, 1998) and, hence, limiting the proliferation and root colonization by phytopathogens (O'sullivan and O'Gara, 1992).

Charcoal rot of sorghum caused by Macrophomina phaseolina, a soil-and seed-borne disease of sorghum, is endemic to tropical and temperate regions of the world (Kumar et al., 2016). Charcoal root causes considerable yield losses due to a lack of genetic-resistant sorghum varieties. Up to $64 \%$ yield losses are reported in India by this disease during the post-rainy season (Das et al., 2008). In order to control the attack of this phytopathogen (Gopalakrishnan et al., 2011), isolated siderophore-positive PSB, Pseudomonas plecoglossicida, B. altitudinis, E. ludwigii, Acinetobacter tandoii, and P. monteilii from the rhizospheres of a system of rice intensification (SRI) fields and tested their biocontrol activity against $M$. phaseolina. Interestingly, all PSB showed strong 
antagonistic activity in dual culture assay, blotter paper assay, and in vivo greenhouse and inhibited the growth of M. phaseolina. No charcoal rot infection was observed in P. plecoglossicida-treated sorghum roots indicating the complete inhibition of pathogen whereas the roots treated with other isolates had 49-76\% less charcoal rot infection compared to the control. All PSB increased root and shoot dry mass by 15-20\% and 15-23\% over control under greenhouse experiment. Also, all PSB adapted well to the sorghum rhizosphere as indicated by the reduction in charcoal rot disease. Similar antifungal activities (inhibition of growth, biomass, microsclerotia production, spore germination) of the secondary metabolites (antifungal volatile and siderophores) and the cell-free culture filtrates (CFCFs) of the selected fluorescent pseudomonad strains (SRB129, SRB288, and Pseudomonas chlororaphis SRB127) against the mycelial growth of $M$. phaseolina that varied from 30.5 to $76.5 \%$ in dual culture assay is reported (Das et al., 2008) The CFCF of the fluorescent pseudomonads@20\% (v/v) significantly decreased the formation and germination of microsclerotia of M. phaseolina. Siderophore-positive bacterium $P$. chlororaphis (SRB127) controlled the charcoal rot of sorghum most efficiently under field conditions. As seed treatment, the bacterium reduced the charcoal rot incidence by $>40 \%$ and crop-lodging by $>20 \%$ and increased the sorghum grain mass. Under glasshouse conditions, the bacterium survived in the sorghum rhizosphere without any significant reduction in its population. Similarly, Streptomyces isolated from medicinal plant rhizosphere inhibited the fungal activity of phytopathogenic fungi A. brassicicola, C. gloeosporioides, Fusarium oxysporum, P. digitatum, and S. rolfsii through siderophores (Khamna et al., 2009). de Los Santos-Villalobos et al. (2012) reported the inhibition of Colletotrichum species (causing anthracnose in sorghum) due to the release of hydroxamate siderophore by $B$. cepacia in a Petri-dish bioassay test. Interestingly, even the lowest concentration $\left(0.64 \mu \mathrm{g} \mathrm{ml}^{-1}\right)$ of siderophore inhibited the pathogen by $91 \%$. Other phytopathogenic fungi capable of inflicting damage to sorghum for example, grain mold diseases of sorghum (Aspergillus and Penicillium) has also been controlled by siderophore rich culture and free supernatant of Alcaligenes sp., and P. aeruginosa (Sayyed and Patel, 2011). The siderophore based biological control measures, therefore, be adopted in sorghum cultivation practices due to reasons, as they are (i) inexpensive and non-destructive (safer) for the environment; (ii) self-replicating and do not require repeat application; and (iii) there is no emergence of resistance among target organisms (Sayyed et al., 2004).

\section{Growth Modulating Enzyme}

Production of 1-aminocyclopropane-1-carboxylate (ACC) deaminase by PSM is considered yet another most powerful management biological weapon for plants growing under abiotic stress (Glick, 2014). After infection by phytopathogens, ethylene, a stress hormone is produced in all higher plants, which causes senescence, chlorosis, abscission, and wilting in plants, worsening the detrimental impact of pathogens (Dubois et al., 2018; Sharma et al., 2019; Etesami and Glick, 2020). The damaging impact of stress hormone can be annulled by the ACC deaminase, a multimeric enzyme, secreted by PSM bacteria (Zhao et al., 2021), fungi (Aban et al., 2017), and actinomycetes (Chukwuneme et al., 2020), which cleaves ACC (precursor of ethylene) to produce $\alpha$-ketobutyrate and ammonia and thereby decreases the ethylene levels in host plants (Gupta and Pandey, 2019; Orozco-Mosqueda et al., 2021). The decrease in the levels of ACC and ethylene prevents the ethylene-mediated plant growth inhibition. PSM endowed with this capability can benefit the sorghum plants by reducing the stress and increasing plant growth (Santana et al., 2020). As an example, (Mareque et al., 2015) reported that the majority of the PSB, such as Pantoea, Enterobacter, Serratia, Pseudomonas, Acinetobacter, and Stenotrophomonas (Gammaproteobacteria phylum), Achromobacter, Herbaspirillum, and Ralstonia (Betaproteobacteria), Rhizobium (Alphaproteobacteria), Chryseobacterium (Bacterioidetes), Bacillus, Staphylococcus, Brevibacillus, and Paenibacillus (Firmicutes), and Kocuria (Actinobacteria), isolated from roots and stems of sweet sorghum plants exhibited ACC deaminase activity. Of these, ACC deaminase positive Rhizobium sp. UYSB13 and PSB bacterium Pantoea sp. UYSB45 showed a significant difference from the negative control in the stem height and dry weight (roots and shoots). Additionally, the ACC deaminase positive Rhizobium sp. UYSB12 and Enterobacter sp. UYSB34 significantly enhanced the root and the shoot dry weights of sweet sorghum.

\section{Antimicrobials}

The antibiotic-mediated inhibition of plant pathogens by rhizosphere-inhabiting biocontrol microorganisms is well (Babalola, 2010; Raaijmakers and Mazzola, 2012) are the most common and have been used in disease management through antibiotics, for example, the suppression of take all disease in wheat by 2,4-diacetylphloroglucinol (Weller et al., 2007). A variety of antibiotics have been identified: amphisin, 2,4-diacetylphloroglucinol (DAPG), oomycin A, phenazine, pyoluteorin, pyrrolnitrin, tensin, tropolone, and cyclic lipopeptides produced by pseudomonads (Raaijmakers and Mazzola, 2012; Saraf et al., 2014), and oligomycin A, kanosamine, zwittermicin A, and xanthobaccin produced by Bacillus, Streptomyces, and (Milner et al., 1996; Hashidoko et al., 1999; Mavrodi et al., 2012) diffusible products like 2, 4-diacetylphloroglucinol, phenazines, pyoluteorin, pyrrolnitrin, etc., or volatile compounds such as dimethyl disulfide, cyanogenic compounds, etc. (Olanrewaju and Babalola, 2019; Pandey and Gupta, 2020). One problem in depending too much on PSM-based antibiotics as biocontrol agents is, however, that with the increased use of PSM, phytopathogens may also develop resistance to microbe-mediated antibiotics in a manner similar to those exhibited for conventional antibiotics. This can though, be obviated by incorporating an HCN-positive PSM (Mahdi et al., 2020) with antibiotics producing PSM (Hamdali et al., 2008) so that the HCN-positive strain kills the pathogens while avoiding the emergence of antibiotic resistance among phytopathogens. The combination of $\mathrm{HCN}$ and antibiotics positive PSM looks a promising strategy that will synergistically control the phytopathogen attack. 


\section{Hydrolytic Enzymes}

A number of hydrolytic enzymes, such as, cellulases, chitinase, $\beta$-1,3-glucanase, protease, lipase, and peroxidase, are released by the PSM (Liu et al., 2016; Nandimath et al., 2017). The cell wall of plant pathogenic fungi, for instance F. oxysporum, is mainly composed of $\beta$-1,3-glucan layers that are highly susceptible to lysis by $\beta$-1,3-glucanase. Following degradation, there occurs the leakage of inner cellular contents to the exterior environment and, finally, due to the osmotic imbalance, the pathogenic fungi collapses (Singh et al., 1999). For instance, some PSFs, such as Acrocalymma sp., otryobambusa fusicoccum, and Phoma sp., produce lytic enzymes such as chitinases and glucanases (Silveira et al., 2021) and catalase and cellulases (Amin et al., 2020), and many PS actinomycetes such as S. fulvissimus, Streptoverticillium olivoverticillatum, S. nogalater, S. longisporoflavus, and S. cellulosae produce cellulase, chitinase, pectinase, lipase, and amylase (Nandimath et al., 2017), which lyse the cell walls of pathogenic fungi attacking sorghum. Similarly, number of PSB belonging to the genera Chrysobacterium, Bacillus, Pseudomonas, Mycobacterium, Staphylococcus, Curtobacterium, Enterobacter, Agrobacterium, Ochrobactrum, Serratia, Stenotrophomonas, and Acinetobacter produced lytic enzymes, such as proteases, celluloses, lipases, esterases, and amylases, which exhibited activity against Fusarium, Aspergillus, and Colletotrichum (Herrera-Quiterio et al., 2020). In a similar study, phosphate solubilizing B. subtilis BN1 isolated from the chirpine (Pinus roxburghii) rhizosphere exhibited strong antagonistic activity resulting in vacuolation, hyphal squeezing, swelling, abnormal branching, and lysis of M. phaseolina, F. oxysporum, and $R$. solani. The inhibition of fungal growth by B. subtilis $\mathrm{BN1}$ was attributed due to the secretion of lytic enzymes, chitinase, and $\beta$-1,3-glucanase, which degrades the hyphae and digest the fungal cell wall (Singh et al., 2008). The CFCF of $\mathrm{BN} 1$ also showed a strong but concentration-dependent antifungal activity and completely inhibited the fungal growth at 60\% CFCF concentration. Pseudomonas putida in yet another experiment demonstrated antifungal activity against A. alternata, F. oxysporum, and $R$. solani through chitinase, $\beta-1,3$ glucanase, salicylic acid, siderophore, and HCN (Selvakumar et al., 2009). The PS bacterium Serratia marcescens inhibited the growth of Sclerotium rolfsii (Ordentlich et al., 1988) while Paenibacillus sp. strain 300 and actinomycetes Streptomyces sp. strain 385 suppressed F. oxysporum fsp. Cucumerinum. Extracellular chitinase and laminarinase synthesized by Pseudomonas stutzeri degraded the mycelia of $F$. solani (Lim et al., 1991). These and other related studies that are not included in this review suggests that, in the absence of high level of genetic resistance in high-yielding sorghum varieties, the PSM as bio-antagonists could safely be used to effectively manage the biotic stresses of sorghum and hence to reduce losses in yield and quality of sorghum cultivated in different regions of the world.

\section{CONCLUSION}

The unwarranted and imprudent application of agrochemicals in sorghum cultivation practices and their hazardous impact on the soil environment warrants the use of a low-cost and environmentally friendly P-solubilizing microbiome as a prospective alternative to $\mathrm{P}$ fertilizers and pesticides. Due to the exorbitant cost of chemical fertilizers, harmful impact of pesticides, and lack of high level of genetic resistance, the novel PSM discovered so far and discussed herein applied either alone or in synergism with compatible organisms can be a useful component in the management of $\mathrm{P}$ fertilization, yield optimization, and integrated sorghum disease management. The application of PSM-based (microphos) formulations in sorghum cultivation is likely to provide economic benefit to sorghum growers while reducing the risk of environmental pollution.

\section{Future Prospects}

The studies surveyed and presented herein are though directly relevant to improving food production, deciphering the detailed molecular and ecological relationships between PSM, $\mathrm{N}_{2}$ fixers, and AM-fungi is indispensable to developing a better understanding of the synergistic relationship between three functionally divergent groups of the soil microbiome. Also, the rhizosphere competence and colonization effect of different PSM strains and their interaction with functionally unrelated plant beneficial bacteria should further be investigated under complex and variable natural conditions with the aim of producing "microphos: PSM based biofertilizer" to alleviate the biotic stresses and consequently augmenting sweet sorghum production in different agroecosystems. Continued research is, however, needed to develop novel strategies to ameliorate the yield and upgrade the efficiency of PSM to manage the attack of phytopathogens causing huge losses to sweet sorghum in variable agroclimatic conditions. To achieve this, scientists, institutions, and manufacturers need to work together to find solutions to nutrition and disease management and to optimize sorghum yield to eradicate hunger worldwide.

\section{AUTHOR CONTRIBUTIONS}

All authors listed have made substantial, direct and intellectual contributions to the work, and approved it for publication.

\section{FUNDING}

This work was supported by the Priority Research Centers Program through the National Research Foundation of Korea (NRF) funded by the Ministry of Education (2014R1A6A1031189) to JL and also supported by the NRF grant funded by the Korean government (MSIT; 2021R1G1A1094698) to BA.

\section{ACKNOWLEDGMENTS}

One of the authors, AR, is thankful to DST-SERB for National Post-doctoral Fellowship (PDF/2020/000127). 


\section{REFERENCES}

Aallam, Y., Dhiba, D., Lemriss, S., Souiri, A., Karray, F., El Rasafi, T., et al. (2021). Solation and characterization of phosphate solubilizing Streptomyces sp. endemic from sugar beet fields of the Beni-Mellal region in Morocco. Microorganisms 9:914. doi: 10.3390/microorganisms9050914

Aban, J. L., Barcelo, R. C., Oda, E. E., Reyes, G. A., Balangcod, T. D., Gutierrez, R. M., et al. (2017). Auxin production, phosphate solubilisation and ACC deaminase activity of root symbiotic fungi (RSF) from Drynaria quercifolia L. Bull. Environ. Pharmacol. Life Sci. 6, 26-31.

Abawari, R. A., Tuji, F. A., and Yadete, D. M. (2020). Phosphate solubilizing bio-fertilizers and their role in bio-available $\mathrm{P}$ nutrient: an overview. Int. J. Appl. Agric. Sci. 6, 162-171. doi: 10.11648/j.ijaas.20200606.11

Abreha, K. B., Ortiz, R., Carlsson, A. S., and Geleta, M. (2021). Understanding the sorghum-Colletotrichum sublineola interactions for enhanced host resistance. Front. Plant Sci. 12:641969. doi: 10.3389/fpls.2021.641969

Adesemoye, A. O., and Kloepper, J. W. (2009). Plant-microbes interactions in enhanced fertilizer-use efficiency. Appl. Microbiol. Biotechnol. 85, 1-12. doi: 10.1007/s00253-009-2196-0

Afifi, M. M. I., El-Sayed, G. A. M., Manal, A., El-Gamal, H., and Massoud, O. N. (2014). Synergistic effect of biofertilizers containing N-fixer, P and K solubilizers and humic substances on Sorghum bicolor productivity. Middle East J. Appl. Sci. 4, 1065-1074.

Ahmed, B., Zaidi, A., Khan, M. S., Rizvi, A., Saif, S., and Shahid, M. (2017). "Perspectives of plant growth promoting rhizobacteria in growth enhancement and sustainable production of tomato," in Microbial Strategies for Vegetable Production. eds. A. Zaidi and M. Khan (Cham, Switzerland: Springer), 125-149.

Akinrinlola, R. J., Yuen, G. Y., Drijber, R. A., and Adesemoye, A. O. (2018). Evaluation of bacillus strains for plant growth promotion and predictability of efficacy by in vitro physiological traits. Int. J. Microbiol. 2018, 1-11. doi: $10.1155 / 2018 / 5686874$

Alagawadi, A. R., and Gaur, A. C. (1988). Interaction between Azospirillum brasilense and phosphate solubilizing bacteriaand their influence on yield and nutrient uptake of sorghum (Sorghum bicolor L.). Zentralbl. Mikrobiol. 143, 637-643. doi: 10.1016/S0232-4393(88)80090-8

Alagawadi, A. R., and Gaur, A. C. (1992). Inoculation of Azospirillum brasilense and phosphate-solubilizing bacteria on yield of sorghum [Sorghum bicolor (L.) Moench] in dry land. Trop. Agric. 69, 347-350.

Alekhya, G., and Gopalakrishnan, S. (2016). Plant growth-promotion by Streptomyces spp. in sorghum (Sorghum bicolor L.). Afr. J. Biotechnol. 15, 1781-1788. doi: 10.5897/AJB2016.15423

Ali, S., Khan, S. A., Hamayun, M., Iqbal, A., Khan, A. L., Hussain, A., et al. (2019). Endophytic fungi from Caralluma acutangula can secrete plant growth promoting enzymes. Fresenius Environ. Bull. 28, 2688-2696.

Almodares, A., and Hadi, M. R. (2009). Production of bioethanol from sweet sorghum: a review. Afr. J. Agric. Res. 4, 772-780.

Alori, E. T., Glick, B. R., and Babalola, O. O. (2017). Microbial phosphorus solubilization and its potential for use in sustainable agriculture. Front. Microbiol. 8:971. doi: 10.3389/fmicb.2017.00971

Amin, B. A. Z., Farhan, H., Hina, A., Muhammad, A., Akhtar, I., Usman, I., et al. (2020). Characterization and cellulolytic enzyme potential of $\mathrm{P}$ solubilizers from pine forests of lower Himalaya. Int. J. Agric. Biol. 24, $1242-1250$.

Asea, P. E. A., Kucey, R. M. N., and Stewart, J. W. B. (1988). Inorganic phosphate solubilization by two Penicillium species in solution culture and soil. Soil Biol. Biochem. 20, 459-464. doi: 10.1016/0038-0717(88)90058-2

Asuming-Brempong, S., and Anipa, B. (2014). The use of rock phosphate and phosphate solubilising fungi (aspergillus Niger) to improve the growth and the yield of upland rice on typic kandiudalf. West Afr J. App. Ecol. 22, $27-39$.

Audenaert, K., Pattery, T., Cornelis, P., and Höfte, M. (2002). Induction of systemic resistance to Botrytis cinerea in tomato by Pseudomonas aeruginosa 7NSK2: role of salicylic acid, pyochelin, and pyocyanin. Mol. Plant-Microbe Interact. 15, 1147-1156. doi: 10.1094/MPMI.2002.15.11.1147

Awika, J. M., and Rooney, L. W. (2004). Sorghum phytochemicals and their potential impact on human health. Phytochemistry 65, 1199-1221. doi: 10.1016/j.phytochem.2004.04.001
Ayyaz, K., Zaheer, A., Rasul, G., and Mirza, M. S. (2016). Isolation and identification by $16 \mathrm{~S}$ rRNA sequence analysis of plant growth-promoting azospirilla from the rhizosphere of wheat. Braz. J. Microbiol. 47, 542-550. doi: $10.1016 /$ j.bjm.2015.11.035

Aziz, T., Sabir, M., Farooq, M., Maqsood, M. A., Ahmad, H. R., and Warraich, E. A. (2014). "Phosphorus deficiency in plants: responses, adaptive mechanisms, and signaling," in Plant Signaling: Understanding the Molecular Crosstalk. eds. K. Hakeem, R. Rehman and I. Tahir (Switzerland: Springer Nature), 133-148.

Babalola, O. O. (2010). Beneficial bacteria of agricultural importance. Biotechnol. Lett. 32, 1559-1570. doi: 10.1007/s10529-010-0347-0

Barcelos, C. A., Maeda, R. N., Santa Anna, L. M. M., and Pereira, N. Jr. (2016). Sweet sorghum as a whole-crop feedstock for ethanol production. Biomass Bioenergy 94, 46-56. doi: 10.1016/j.biombioe.2016.08.012

Batool, S., and Iqbal, A. (2019). Phosphate solubilizing rhizobacteria as alternative of chemical fertilizer for growth and yield of Triticum aestivum (Var. galaxy 2013). Saudi J. Biol. Sci. 26, 1400-1410. doi: 10.1016/j.sjbs.2018.05.024

Bechtaoui, N., Raklami, A., Tahiri, A.-I., Benidire, L., El Alaoui, A., Meddich, A., et al. (2019). Characterization of plant growth promoting rhizobacteria and their benefits on growth and phosphate nutrition of faba bean and wheat. Biol. Open 8:bio043968. doi: 10.1242/bio.043968

Behera, B. C., Yadav, H., Singh, S. K., Mishra, R. R., Sethi, B. K., Dutta, S. K., et al. (2017). Phosphate solubilization and acid phosphatase activity of Serratia sp. isolated from mangrove soil of Mahanadi river delta, Odisha, India. J. Genet. Eng. Biotechnol. 15, 169-178. doi: 10.1016/j.jgeb.2017.01.003

Bhardwaj, D., Ansari, M. W., Sahoo, R. K., and Tuteja, N. (2014). Biofertilizers function as key player in sustainable agriculture by improving soil fertility, plant tolerance and crop productivity. Microb. Cell Factories 13:66. doi: 10.1186/1475-2859-13-66

Bjelić, D., Marinković, J., Tintor, B., Tančić, S., Nastasić, A., and Mrkovački, N. (2015). Screening of Azotobacter isolates for PGP properties and antifungal activity. Zb. Matice Srp. Prir. Nauk. 65-72. doi: 10.2298/ZMSPN1529065B

Boubekri, K., Soumare, A., Mardad, I., Lyamlouli, K., Hafidi, M., Ouhdouch, Y., et al. (2021). The screening of potassium-and phosphate-solubilizing actinobacteria and the assessment of their ability to promote wheat growth parameters. Microorganisms 9:470. doi: 10.3390/microorganisms9030470

Brady, C. R., Noll, L. W., Saleh, A. A., and Little, C. R. (2011). Disease severity and microsclerotium properties of the sorghum sooty stripe pathogen, Ramulispora sorghi. Plant Dis. 95, 853-859. doi: 10.1094/PDIS-10-10-0742

Chaiharn, M., Pathom-Aree, W., Sujada, N., and Lumyong, S. (2018). Characterization of phosphate solubilizing Streptomyces as a biofertilizer. Chiang Mai J. Sci. 45, 701-716.

Chawngthu, L., Hnamte, R., and Lalfakzuala, R. (2020). Isolation and characterization of rhizospheric phosphate solubilizing bacteria from wetland paddy field of Mizoram, India. Geomicrobiol J. 37, 366-375. doi: 10.1080/01490451.2019.1709108

Chen, Q., and Liu, S. (2019). Identification and characterization of the phosphatesolubilizing bacterium Pantoea sp. S32 in reclamation soil in Shanxi, China. Front. Microbiol. 10:2171. doi: 10.3389/fmicb.2019.02171

Chen, J., Zhao, G., Wei, Y., Dong, Y., Hou, L., and Jiao, R. (2021). Isolation and screening of multifunctional phosphate solubilizing bacteria and its growth-promoting effect on Chinese fir seedlings. Sci. Rep. 11:9081. doi: 10.1038/s41598-021-88635-4

Choudhary, D. K., Kasotia, A., Jain, S., Vaishnav, A., Kumari, S., Sharma, K. P., et al. (2016). Bacterial-mediated tolerance and resistance to plants under abiotic and biotic stresses. J. Plant Growth Regul. 35, 276-300. doi: 10.1007/ s00344-015-9521-x

Chouyia, F. E., Romano, I., Fechtali, T., Fagnano, M., Fiorentino, N., Visconti, D., et al. (2020). P-solubilizing Streptomyces roseocinereus MS1B15 with multiple plant growth-promoting traits enhance barley development and regulate rhizosphere microbial population. Front. Plant Sci. 11:1137. doi: 10.3389/fpls.2020.01137

Chu, H., Lin, X., Fujii, T., Morimoto, S., Yagi, K., Hu, J., et al. (2007). Soil microbial biomass, dehydrogenase activity, bacterial community structure in response to long-term fertilizer management. Soil Biol. Biochem. 39, 2971-2976. doi: 10.1016/j.soilbio.2007.05.031

Chukwuneme, C. F., Babalola, O. O., Kutu, F. R., and Ojuederie, O. B. (2020). Characterization of actinomycetes isolates for plant growth promoting traits and their effects on drought tolerance in maize. J. Plant Interact. 15, 93-105. doi: $10.1080 / 17429145.2020 .1752833$ 
Cobb, A. B., Wilson, G. W. T., Goad, C. L., Bean, S. R., Kaufman, R. C., Herald, T. J., et al. (2016). The role of arbuscular mycorrhizal fungi in grain production and nutrition of sorghum genotypes: enhancing sustainability through plant-microbial partnership. Agric. Ecosyst. Environ. 233, 432-440. doi: 10.1016/j.agee.2016.09.024

Danish, S., Zafar-ul-Hye, M., Mohsin, F., and Hussain, M. (2020). ACC-deaminase producing plant growth promoting rhizobacteria and biochar mitigate adverse effects of drought stress on maize growth. PLoS One 15:e0230615. doi: 10.1371/journal.pone.0230615

Dar, R. A., Dar, E. A., Kaur, A., and Phutela, U. G. (2018). Sweet sorghum-a promising alternative feedstock for biofuel production. Renew. Sust. Energ. Rev. 82, 4070-4090. doi: 10.1016/j.rser.2017.10.066

Das, I. K., Aruna, C., and Tonapi, V. A. (2020). Sorghum Grain Mold. Hyderabad, India: ICAR-Indian Institute of Millets Research, 1-86.

Das, I. K., Indira, S., Annapurna, A., and Seetharama, N. (2008). Biocontrol of charcoal rot in sorghum by fluorescent pseudomonads associated with the rhizosphere. Crop Prot. 27, 1407-1414. doi: 10.1016/j.cropro.2008.07.001

Das, I. K., Kumar, S., Kannababu, N., and Tonapi, V. A. (2019). Pokkah boeng resistance in popular rabi sorghum cultivars and effects of the disease on leaf chlorophyll. Indian Phytopathol. 72, 421-426. doi: 10.1007/ s42360-019-00146-5

Das, I. K., and Rajendrakumar, P. (2016). "Disease resistance in sorghum," in Biotic Stress Resistance in Millets. eds. I. K. Das and P. G. Padmaja (Amsterdam, The Netherlands: Elsevier), 23-67.

de Los Santos-Villalobos, S., Barrera-Galicia, G. C., Miranda-Salcedo, M. A., and Peña-Cabriales, J. J. (2012). Burkholderia cepacia XXVI siderophore with biocontrol capacity against Colletotrichum gloeosporioides. World J. Microbiol. Biotechnol. 28, 2615-2623. doi: 10.1007/s11274-012-1071-9

de Sousa, S. M., de Oliveira, C. A., Andrade, D. L., de Carvalho, C. G., Ribeiro, V. P., Pastina, M. M., et al. (2021). Tropical bacillus strains inoculation enhances maize root surface area, dry weight, nutrient uptake and grain yield. J. Plant Growth Regul. 40, 867-877. doi: 10.1007/ s00344-020-10146-9

Díaz-Rodríguez, A. M., Gastelum, L. A. S., Pablos, C. M. F., Parra-Cota, F. I., Santoyo, G., Puente, M. L., et al. (2020). The current and future role of microbial culture collections in food security worldwide. Front. Sustain. Food Syst. 4:614739. doi: 10.3389/fsufs.2020.614739

Dicko, M. H., Gruppen, H., Traoré, A. S., Voragen, A. G. J., and Van Berkel, W. J. H. (2006). Sorghum grain as human food in Africa: relevance of content of starch and amylase activities. Afr. J. Biotechnol. 5, 384-395.

Dierks, J., Blaser-Hart, W. J., Gamper, H. A., Nyoka, I. B., Barrios, E., and Six, J. (2021). Trees enhance abundance of arbuscular mycorrhizal fungi, soil structure, and nutrient retention in low-input maize cropping systems. Agric. Ecosyst. Environ. 318:107487. doi: 10.1016/j.agee.2021.107487

Din, M., Nelofer, R., Salman, M., Khan, F. H., Khan, A., Ahmad, M., et al. (2019). Production of nitrogen fixing Azotobacter (SR-4) and phosphorus solubilizing aspergillus Niger and their evaluation on Lagenaria siceraria and Abelmoschus esculentus. Biotechnol. Rep. 22:e00323. doi: 10.1016/j.btre.2019. e00323

Doilom, M., Guo, J.-W., Phookamsak, R., Mortimer, P. E., Karunarathna, S. C., Dong, W., et al. (2020). Screening of phosphate-solubilizing fungi from air and soil in Yunnan, China: four novel species in Aspergillus, Gongronella, Penicillium, and Talaromyces. Front. Microbiol. 11:585215. doi: 10.3389/ fmicb.2020.585215

dos Santos, C. L. R., Alves, G. C., de Matos Macedo, A. V., Giori, F. G., Pereira, W., Urquiaga, S., et al. (2017). Contribution of a mixed inoculant containing strains of Burkholderia spp. and Herbaspirillum sp. to the growth of three sorghum genotypes under increased nitrogen fertilization levels. Appl. Soil Ecol. 113, 96-106. doi: 10.1016/j.apsoil.2017.02.008

Dubois, M., Van den Broeck, L., and Inzé, D. (2018). The pivotal role of ethylene in plant growth. Trends Plant Sci. 23, 311-323. doi: 10.1016/j. tplants.2018.01.003

Ehteshami, S. M. R., Abbasi, M. R., Khavazi, K., and And Zand, B. (2014). Effect of phosphate solubilizing bacteria strains (Pseudomonas putida) on forage quality and quantity of sorghum cultivars in Varamin. J. Plant Proc. Function 2, 1-11.

El-Badry, M. A., Elbarbary, T. A., Ibrahim, I. A., and Abdel-Fatah, Y. M. (2016). Azotobacter vinelandii evaluation and optimization of Abu Tartur Egyptian phosphate ore dissolution. Saudi J. Pathol. Microbiol 1, 80-93.
El-Dsouky, M. M., Mohamed, H. M., El-Rewainy, H. M., and Farid, A.-S. M. (2019). Effect of inoculation with phosphate solubilizing actinomycete isolates on phosphorous uptake and growth of wheat grown in calcareous sandy soil. Assiut J. Agric. Sci. 50, 307-315. doi: 10.21608/ajas.2019.41287

Elfiati, D., Delvian, D., Hanum, H., Susilowati, A., and Rachmat, H. H. (2021). Potential of phosphate solubilizing fungi isolated from peat soils as inoculant biofertilizer. Biodiversitas J. Biol. Divers. 22, 3042-3048. doi: 10.13057/biodiv/ d220605

Elhaissoufi, W., Khourchi, S., Ibnyasser, A., Ghoulam, C., Rchiad, Z., Zeroual, Y., et al. (2020). Phosphate solubilizing rhizobacteria could have a stronger influence on wheat root traits and aboveground physiology than rhizosphere P solubilization. Front. Plant Sci. 11:979. doi: 10.3389/fpls.2020.00979

Estrella, A. H., and Chet, I. (1998). Biocontrol of bacteria and phytopathogenic fungi. Agric. Biotechnol. 263-282.

Etesami, H., and Glick, B. R. (2020). Halotolerant plant growth-promoting bacteria: prospects for alleviating salinity stress in plants. Environ. Exp. Bot. 178:104124. doi: 10.1016/j.envexpbot.2020.104124

Farhat, M. B., Boukhris, I., and Chouayekh, H. (2015). Mineral phosphate solubilization by Streptomyces sp. CTM396 involves the excretion of gluconic acid and is stimulated by humic acids. FEMS Microbiol. Lett. 362:fnv008. doi: 10.1093/femsle/fnv008

García-Fraile, P., Menéndez, E., and Rivas, R. (2015). Role of bacterial biofertilizers in agriculture and forestry. AIMS Bioeng. 2, 183-205. doi: 10.3934/ bioeng.2015.3.183

Garnett, T., Conn, V., and Kaiser, B. N. (2009). Root based approaches to improving nitrogen use efficiency in plants. Plant Cell Environ. 32, 1272-1283. doi: 10.1111/j.1365-3040.2009.02011.x

Gemenet, D. C., Leiser, W. L., Beggi, F., Herrmann, L. H., Vadez, V., Rattunde, H. F. W., et al. (2016). Overcoming phosphorus deficiency in west African pearl millet and sorghum production systems: promising options for crop improvement. Front. Plant Sci. 7:1389. doi: 10.3389/fpls.2016.01389

Gheliya, K. P., Bhalu, V. B., Mathukia, R. K., Hadavani, J. K., and Kamani, M. D. (2018). Effect of phosphate and potash solubilizing bacteria on growth and yield of popcorn (Zea mays L. var. Everta). Int. J. Pure Appl. Biosci. 6, 167-174. doi: 10.18782/2320-7051.6918

Glick, B. R. (2014). Bacteria with ACC deaminase can promote plant growth and help to feed the world. Microbiol. Res. 169, 30-39. doi: 10.1016/j. micres.2013.09.009

Goldstein, A. H., Rogers, R. D., and Mead, G. (1993). Mining by microbe. Bio/Technology 11, 1250-1254.

Gopalakrishnan, S., Humayun, P., Kiran, B. K., Kannan, I. G. K., Vidya, M. S., Deepthi, K., et al. (2011). Evaluation of bacteria isolated from rice rhizosphere for biological control of charcoal rot of sorghum caused by Macrophomina phaseolina (Tassi) Goid. World J. Microbiol. Biotechnol. 27, 1313-1321. doi: 10.1007/s11274-010-0579-0

Gopalakrishnan, S., Srinivas, V., Prakash, B., Sathya, A., and Vijayabharathi, R. (2015). Plant growth-promoting traits of Pseudomonas geniculata isolated from chickpea nodules. 3 Biotech 5, 653-661. doi: 10.1007/s13205-014-0263-4

Gupta, S., and Pandey, S. (2019). ACC deaminase producing bacteria with multifarious plant growth promoting traits alleviates salinity stress in French bean (Phaseolus vulgaris) plants. Front. Microbiol. 10:1506. doi: 10.3389/ fmicb.2019.01506

Gurdeep, K., and Reddy, M. S. (2015). Effects of phosphate-solubilizing bacteria, rock phosphate and chemical fertilizers on maize-wheat cropping cycle and economics. Pedosphere 25, 428-437. doi: 10.1016/S1002-0160(15)30010-2

Hamane, S., Zerrouk, M. H., Lyemlahi, A. E., Aarab, S., Laglaoui, A., Bakkali, M., et al. (2020). "Screening and characterization of phosphate-solubilizing rhizobia," in Phyto-Microbiome in Stress Regulation. eds. M. Kumar, V. Kumar and R. Prasad (Switzerland: Springer Nature), 113-124.

Hamdali, H., Hafidi, M., Virolle, M. J., and Ouhdouch, Y. (2008). Growth promotion and protection against damping-off of wheat by two rock phosphate solubilizing actinomycetes in a P-deficient soil under greenhouse conditions. Appl. Soil Ecol. 40, 510-517. doi: 10.1016/j.apsoil.2008.08.001

Hameeda, B., Harini, G., Rupela, O. P., Wani, S. P., and Reddy, G. (2008). Growth promotion of maize by phosphate-solubilizing bacteria isolated from composts and macrofauna. Microbiol. Res. 163, 234-242. doi: 10.1016/j. micres.2006.05.009

Harinathan, B., Sankaralingam, S., Palpperumal, S., Kathiresan, D., Shankar, T., and Prabhu, D. (2016). Effect of phosphate solubilizing bacteria on growth 
and development of pearl millet and ragi. J. Adv. Biol. Biotechnol. 7, 1-7. doi: $10.9734 / \mathrm{JABB} / 2016 / 26290$

Hashidoko, Y., Nakayama, T., Homma, Y., and Tahara, S. (1999). Structure elucidation of xanthobaccin A, a new antibiotic produced from Stenotrophomonas sp. strain SB-K88. Tetrahedron Lett. 40, 2957-2960. doi: 10.1016/S0040-4039(99)00336-6

Hasibuan, S., and Nazir, N. (2017). The development strategy of sustainable bioethanol industry on iconic Sumba island, eastern Indonesia. Int. J. Adv. Sci. Eng. Inf. Technol. 7, 276-283. doi: 10.18517/ijaseit.7.1.1796

Hernandez, J., Garrido, M. J., Lopez, O., and Trujillo, G. E. (1992). The bacterial leaf spot of sorghum caused by pseudomonas syringae pv. Syringae in Venezuela. Fitopatol Venez 5, 39-42.

Herrera-Quiterio, A., Toledo-Hernández, E., Aguirre-Noyola, J. L., Romero, Y., Ramos, J., Palemón-Alberto, F., et al. (2020). Antagonic and plant growthpromoting effects of bacteria isolated from mine tailings at El Fraile, Mexico. Rev. Argent. Microbiol. 52, 231-239. doi: 10.1016/j.ram.2019.08.003

Hussein, K. A., and Joo, J. H. (2015). Isolation and characterization of rhizomicrobial isolates for phosphate solubilization and indole acetic acid production. J. Korean Soc. Appl. Biol. Chem. 58, 847-855. doi: 10.1007/ s13765-015-0114-y

Jiang, Y., Xu, J., Hu, L., Liu, K.-J., Xu, X.-D., Liu, Z., et al. (2018). First report of sorghum zonate leaf spot caused by Gloeocercospora sorghi in China. Plant Dis. 102:1033. doi: 10.1094/PDIS-08-17-1217-PDN

Jisha, M. S., and Alagawadi, A. R. (1996). Nutrient uptake and yield of sorghum (Sorghum bicolor L. Moench) inoculated with phosphate solubilizing bacteria and cellulolytic fungus in a cotton stalk amended vertisol. Microbiol. Res. 151, 213-217. doi: 10.1016/S0944-5013(96)80046-2

Johansson, J. F., Paul, L. R., and Finlay, R. D. (2004). Microbial interactions in the mycorrhizosphere and their significance for sustainable agriculture. FEMS Microbiol. Ecol. 48, 1-13. doi: 10.1016/j.femsec.2003.11.012

Jyothi, V., Sowmya, H. V., and Thippeswamy, B. (2020). Siderophore production by phosphate solubilizing fungi from rhizospheric soil of medicinal plants. Int. J. Biol. Biotechnol. 17, 599-606.

Kalam, S., Basu, A., and Podile, A. R. (2020). Functional and molecular characterization of plant growth promoting bacillus isolates from tomato rhizosphere. Heliyon 6:e04734. doi: 10.1016/j.heliyon.2020.e04734

Kalayu, G. (2019). Phosphate solubilizing microorganisms: promising approach as biofertilizers. Int. J. Agron. 2019:4917256. doi: 10.1155/2019/4917256

Kamali, S., and Mehraban, A. (2020). Effects of Nitroxin and arbuscular mycorrhizal fungi on the agro-physiological traits and grain yield of sorghum (Sorghum bicolor L.) under drought stress conditions. PLoS One 15:e0243824. doi: 10.1371/journal.pone.0243824

Kang, J., Amoozegar, A., Hesterberg, D., and Osmond, D. L. (2011). Phosphorus leaching in a sandy soil as affected by organic and inorganic fertilizer sources. Geoderma 161, 194-201. doi: 10.1016/j.geoderma.2010.12.019

Kang, S.-M., Hamayun, M., Khan, M. A., Iqbal, A., and Lee, I.-J. (2019). Bacillus subtilis JW1 enhances plant growth and nutrient uptake of Chinese cabbage through gibberellins secretion. J. Appl. Bot. Food Qual. 92, 172-178. doi: 10.5073/JABFQ.2019.092.023

Keller-Pearson, M., Liu, Y., Peterson, A., Pederson, K., Willems, L., Ane, J.-M., et al. (2020). Inoculation with arbuscular mycorrhizal fungi has a more significant positive impact on the growth of open-pollinated heirloom varieties of carrots than on hybrid cultivars under organic management conditions. Agric. Ecosyst. Environ. 289:106712. doi: 10.1016/j.agee.2019.106712

Khamna, S., Yokota, A., and Lumyong, S. (2009). Actinomycetes isolated from medicinal plant rhizosphere soils: diversity and screening of antifungal compounds, indole-3-acetic acid and siderophore production. World J. Microbiol. Biotechnol. 25, 649-655. doi: 10.1007/s11274-008-9933-x

Khan, M. S., Zaidi, A., and Ahmad, E. (2014). "Mechanism of phosphate solubilization and physiological functions of phosphate-solubilizing microorganisms," in Phosphate Solubilizing Microorganisms. eds. M. Khan, A. Zaidi and J. Musarrat (Switzerland: Springer International Publishing), 31-62.

Khasa, Y. P. (2017). "Microbes as biocontrol agents," in Probiotics and Plant Health. eds. V. Kumar, M. Kumar, S. Sharma and R. Prasad (Switzerland: Springer), 507-552.

Khatoon, Z., Huang, S., Rafique, M., Fakhar, A., Kamran, M. A., and Santoyo, G. (2020). Unlocking the potential of plant growth-promoting rhizobacteria on soil health and the sustainability of agricultural systems. J. Environ. Manag. 273:111118. doi: 10.1016/j.jenvman.2020.111118
Kimball, J., Cui, Y., Chen, D., Brown, P., Rooney, W. L., Stacey, G., et al. (2019). Identification of QTL for target leaf spot resistance in Sorghum bicolor and investigation of relationships between disease resistance and variation in the MAMP response. Sci. Rep. 9:18285. doi: 10.1038/ s41598-019-54802-x

Kouas, S., Labidi, N., Debez, A., and Abdelly, C. (2005). Effect of P on nodule formation and $\mathrm{N}$ fixation in bean. Agron. Sustain. Dev. 25, 389-393. doi: 10.1051/agro:2005034

Kuan, K. B., Othman, R., Abdul Rahim, K., and Shamsuddin, Z. H. (2016). Plant growth-promoting rhizobacteria inoculation to enhance vegetative growth, nitrogen fixation and nitrogen remobilisation of maize under greenhouse conditions. PLoS One 11:e0152478. doi: 10.1371/journal. pone. 0152478

Kulamarva, A. G., Sosle, V. R., and Raghavan, G. S. V. (2009). Nutritional and rheological properties of sorghum. Int. J. Food Prop. 12, 55-69. doi: $10.1080 / 10942910802252148$

Kumar, P., Aeron, A., Shaw, N., Singh, A., Bajpai, V. K., Pant, S., et al. (2020). Seed bio-priming with tri-species consortia of phosphate solubilizing rhizobacteria (PSR) and its effect on plant growth promotion. Heliyon 6:e05701. doi: 10.1016/j.heliyon.2020.e05701

Kumar, A. A., Gorthy, S., Sharma, H. C., Huang, Y., Sharma, R., and Reddy, B. V. S. (2014). "Understanding genetic control of biotic stress resistance in sorghum for applied breeding," in Genetics, Genomics and Breeding of Sorghum. Florida, USA: CRC Press, 220-247.

Kumar, P., Gupta, V., Tiwari, A., and Kamle, M. (2016). "Macrophomina phaseolina: the most destructive soybean fungal pathogen of global concern," in Current Trends in Plant Disease Diagnostics and Management Practices, Fungal Biology. Switzerland: Springer Nature, 1-11.

Kumar, A. P. K., McKeown, P. C., Boualem, A., Ryder, P., Brychkova, G., Bendahmane, A., et al. (2017a). TILLING by sequencing (TbyS) for targeted genome mutagenesis in crops. Mol. Breeding 37:14. doi: 10.1007/ s11032-017-0620-1

Kumar, G. K., and Ram, M. R. (2014). Phosphate solubilizing rhizobia isolated from Vigna trilobata. Am. J. Microbiol. Res. 2, 105-109. doi: 10.12691/ ajmr-2-3-4

Kumar, S. V., Sajeevkumar, V. A., George, J., and Kumar, S. (2017b). Enhancing properties of polyvinyl alcohol film using sorghum starch nanocrystals. Defence Life Sci. J. 2, 169-177. doi: 10.14429/dlsj.2.11380

Lebrazi, S., Niehaus, K., Bednarz, H., Fadil, M., Chraibi, M., and Fikri-Benbrahim, K. (2020). Screening and optimization of indole-3-acetic acid production and phosphate solubilization by rhizobacterial strains isolated from Acacia cyanophylla root nodules and their effects on its plant growth. J. Genet. Eng. Biotechnol. 18:71. doi: 10.1186/s43141-020-00090-2

Léder, I. (2004). Sorghum and millets. Cultivated Plants, primarily as food sources. EOLSS 1, 66-84.

Li, Z., Bai, T., Dai, L., Wang, F., Tao, J., Meng, S., et al. (2016). A study of organic acid production in contrasts between two phosphate solubilizing fungi: Penicillium oxalicum and aspergillus Niger. Sci. Rep. 6:25313. doi: $10.1038 /$ srep25313

Li, Y., Wang, C., Wang, T., Liu, Y., Jia, S., Gao, Y., et al. (2020). Effects of different fertilizer treatments on rhizosphere soil microbiome composition and functions. Land 9:329. doi: 10.3390/land9090329

Lim, H.-S., Kim, Y.-S., and Kim, S.-D. (1991). Pseudomonas stutzeri YPL-1 genetic transformation and antifungal mechanism against Fusarium solani, an agent of plant root rot. Appl. Environ. Microbiol. 57, 510-516. doi: 10.1128/ aem.57.2.510-516.1991

Liu, G., Deng, L., Wu, R., Guo, S., Du, W., Yang, M., et al. (2020). Determination of nitrogen and phosphorus fertilisation rates for tobacco based on economic response and nutrient concentrations in local stream water. Agric. Ecosyst. Environ. 304:107136. doi: 10.1016/j.agee.2020.107136

Liu, G., Han, Y., Jiang, Y., Wang, Y., Lv, P., and Li, H. (2016). "Genomics approaches to biotic stress resistance," in The Sorghum Genome. eds. S. Rakshit and Y. H. Wang (Switzerland: Springer Nature), 149-167.

Lobo, L. L. B., dos Santos, R. M., and Rigobelo, E. C. (2019). Promotion of maize growth using endophytic bacteria under greenhouse and field conditions. Aust. J. Crop. Sci. 13, 2067-2074. doi: 10.21475/ajcs.19.13.12.p2077

Mahdi, I., Fahsi, N., Hafidi, M., Allaoui, A., and Biskri, L. (2020). Plant growth enhancement using rhizospheric halotolerant phosphate solubilizing bacterium Bacillus licheniformis QA1 and Enterobacter asburiae QF11 isolated from 
Chenopodium quinoa willd. Microorganisms 8:948. doi: 10.3390/ microorganisms8060948

Mahmoud, A. F., Abou-Elwafa, S. F., and Shehzad, T. (2018). Identification of charcoal rot resistance QTLs in sorghum using association and in silico analyses. J. Appl. Genet. 59, 243-251. doi: 10.1007/s13353-018-0446-5

Maldonado, S., Rodríguez, A., Ávila, B., Morales, P., González, M. P., Araya Angel, J. P. A., et al. (2020). Enhanced crop productivity and sustainability by using native phosphate solubilizing rhizobacteria in the agriculture of arid zones. Front. Sustain. Food Syst. 4:607355. doi: 10.3389/fsufs.2020.607355

Mareque, C., Taulé, C., Beracochea, M., and Battistoni, F. (2015). Isolation, characterization and plant growth promotion effects of putative bacterial endophytes associated with sweet sorghum (Sorghum bicolor (L) Moench). Ann. Microbiol. 65, 1057-1067. doi: 10.1007/s13213-014-0951-7

Mareya, C. R., Tugizimana, F., Di Lorenzo, F., Silipo, A., Piater, L. A., Molinaro, A., et al. (2020). Adaptive defence-related changes in the metabolome of Sorghum bicolor cells in response to lipopolysaccharides of the pathogen Burkholderia andropogonis. Sci. Rep. 10:7626. doi: 10.1038/s41598-020-64186-y

Marles, J., Apriyanto, E., and Harsono, P. (2018). Growth and yield response of three sorghum varieties in coastal land using organic materials and arbuscular mycorrhizal fungi. Naturalis 7, 29-40.

Matos, A. D. M., Gomes, I. C. P., Nietsche, S., Xavier, A. A., Gomes, W. S., Dos Santos, J. A., et al. (2017). Phosphate solubilization by endophytic bacteria isolated from banana trees. An. Acad. Bras. Cienc. 89, 2945-2954. doi: 10.1590/0001-3765201720160111

Mattos, B. B., Marriel, I. E., De Sousa, S. M., Lana, U. G. D. E. P., Schaffert, R. E., Gomes, E. A., et al. (2020). Sorghum genotypes response to inoculation with phosphate solubilizing bacteria. Brazilian J. Maize Sorghum 19:14. doi: 10.18512/rbms2020v19e1177

Mavrodi, D. V., Mavrodi, O. V., Parejko, J. A., Bonsall, R. F., Kwak, Y.-S., Paulitz, T. C., et al. (2012). Accumulation of the antibiotic phenazine-1carboxylic acid in the rhizosphere of dryland cereals. Appl. Environ. Microbiol. 78, 804-812. doi: 10.1128/AEM.06784-11

Mendoza-Arroyo, G. E., Chan-Bacab, M. J., Aguila-Ramírez, R. N., Ortega-Morales, B. O., Canché Solís, R. E., Chab-Ruiz, A. O., et al. (2020). Inorganic phosphate solubilization by a novel isolated bacterial strain Enterobacter sp. ITCB-09 and its application potential as biofertilizer. Agriculture 10:383. doi: 10.3390/agriculture10090383

Menéndez, E., Pérez-Yépez, J., Hernández, M., Rodríguez-Pérez, A., Velázquez, E., and León-Barrios, M. (2020). Plant growth promotion abilities of phylogenetically diverse Mesorhizobium strains: effect in the root colonization and development of tomato seedlings. Microorganisms 8:412. doi: 10.3390/ microorganisms 8030412

Milner, J. L., Silo-Suh, L., Lee, J. C., He, H., Clardy, J., and Handelsman, J. O. (1996). Production of kanosamine by Bacillus cereus UW85. Appl. Environ. Microbiol. 62, 3061-3065. doi: 10.1128/aem.62.8.3061-3065.1996

Mitra, D., Anđelković, S., Panneerselvam, P., Senapati, A., Vasić, T., Ganeshamurthy, A. N., et al. (2020). Phosphate-solubilizing microbes and biocontrol agent for plant nutrition and protection: current perspective. Commun. Soil Sci. Plant Anal. 51, 645-657. doi: 10.1080/00103624.2020.1729379

Mohamed, A. A., Eweda, W. E. E., Heggo, A. M., and Hassan, E. A. (2014). Effect of dual inoculation with arbuscular mycorrhizal fungi and Sulphuroxidising bacteria on onion (Allium cepa L.) and maize (Zea mays L.) grown in sandy soil under green house conditions. Ann. Agric. Sci. 59, 109-118. doi: 10.1016/j.aoas.2014.06.015

Mohamed, E. A. H., Farag, A. G., and Youssef, S. A. (2018). Phosphate solubilization by Bacillus subtilis and Serratia marcescens isolated from tomato plant rhizosphere. J. Environ. Prot. 9, 266-277. doi: 10.4236/jep.2018.93018

Mohammed, A. F. (2020). Influence of Streptomyces sp. Kp109810 on solubilization of inorganic phosphate and growth of maize (Zea mays L.). J. Appl. Plant Prot. 9, 17-24. doi: 10.21608/japp.2020.130644

Moharam, M. H. A. (2018). First report of loose kernel smut of sorghum caused by Sporisorium cruentum in Egypt. New Dis. Rep. 37:9. doi: 10.5197/ j.2044-0588.2018.037.009

Mojid, M. A., Wyseure, G. C. L., and Biswas, S. K. (2012). Requirement of nitrogen, phosphorus and potassium fertilizers for wheat cultivation under irrigation by municipal wastewater. J. Soil Sci. Plant Nutr. 12, 655-665. doi: 10.4067/S0718-95162012005000023

Muleta, A., Tesfaye, K., Selassie, T. H. H., Cook, D. R., and Assefa, F. (2021). Phosphate solubilization and multiple plant growth promoting properties of Mesorhizobium species nodulating chickpea from acidic soils of Ethiopia. Arch. Microbiol. 203, 2129-2137. doi: 10.1007/s00203-021-02189-7

Munir, I., Bano, A., and Faisal, M. (2019). Impact of phosphate solubilizing bacteria on wheat (Triticum aestivum) in the presence of pesticides. Braz. J. Biol. 79, 29-37. doi: 10.1590/1519-6984.172213

Munir, I., Ranjha, A. M., Sarfraz, M., Obaid-ur-Rehman, Mehdiand, S. M., and Mahmood, K. (2004). Effect of residual phosphorus on sorghum fodder in two different texturedsoils. Int. J. Agric. Biol. 6, 967-969.

Murty, D. S., and Subramanian, V. (1982). Sorghum roti: I. Traditional methods of consumption and standard procedures for evaluation. 73-78.

Nacoon, S., Jogloy, S., Riddech, N., Mongkolthanaruk, W., Kuyper, T. W., and Boonlue, S. (2020). Interaction between phosphate solubilizing bacteria and arbuscular mycorrhizal fungi on growth promotion and tuber inulin content of Helianthus tuberosus L. Sci. Rep. 10:4916. doi: 10.1038/s41598-020-61846-x

Nandimath, A. P., Karad, D. D., Gupta, S. G., and Kharat, A. S. (2017). Consortium inoculum of five thermo-tolerant phosphate solubilizing Actinomycetes for multipurpose biofertilizer preparation. Iran. J. Microbiol. 9:295.

Naseri, R., Barary, M., Zarea, M. J., Khavazi, K., Tahmasebi, Z., and Yaghotipoor, A. (2018). Effect of phosphate solubilizing bacteria and mycorrhizal fungi on phenological and physiological characteristics of wheat under dryland conditions. J. Crop Ecophysiol. 12, 211-236.

Naziya, B., Murali, M., and Amruthesh, K. N. (2020). Plant growth-promoting fungi (PGPF) instigate plant growth and induce disease resistance in Capsicum annuum L. upon infection with Colletotrichum capsici (Syd.) Butler \& Bisby. Biomol. Ther. 10:41. doi: 10.3390/biom10010041

Nepomuceno, R. A., Brown, C. M. B., Mojica, P. N., and Brown, M. B. (2019). Biological control potential of vesicular arbuscular mycorrhizal root inoculant (VAMRI) and associated phosphate solubilizing bacteria, Pseudochrobactrum asaccharolyticum against soilborne phytopathogens of onion (Allium cepa L. var. red creole). Arch. Phytopathol. Plant Protect. 52, 714-732. doi: 10.1080/03235408.2019.1644058

Nigusie, Z., and Ademe, A. (2020). Evaluation of insecticidal botanicals against sorghum covered smut (Sphacelotheca sorghi) at Wag-Lasta areas, Ethiopia. Cogent Food Agric. 6:1745132. doi: 10.1080/23311932.2020.1745132

Nogales, A., Rottier, E., Campos, C., Victorino, G., Costa, J. M., Coito, J. L., et al. (2021). The effects of field inoculation of arbuscular mycorrhizal fungi through rye donor plants on grapevine performance and soil properties. Agric. Ecosyst. Environ. 313:107369. doi: 10.1016/j.agee.2021.107369

Nosrati, R., Owlia, P., Saderi, H., Rasooli, I., and Malboobi, M. A. (2014). Phosphate solubilization characteristics of efficient nitrogen fixing soil Azotobacter strains. Iran. J. Microbiol. 6:285.

O’sullivan, D. J., and O'Gara, F. (1992). Traits of fluorescent Pseudomonas spp. involved in suppression of plant root pathogens. Microbiol. Rev. 56, 662-676. doi: $10.1128 / \mathrm{mr} .56 .4 .662-676.1992$

Olanrewaju, O. S., and Babalola, O. O. (2019). Streptomyces: implications and interactions in plant growth promotion. Appl. Microbiol. Biotechnol. 103, 1179-1188. doi: 10.1007/s00253-018-09577-y

Olanrewaju, O. S., Glick, B. R., and Babalola, O. O. (2017). Mechanisms of action of plant growth promoting bacteria. World J. Microbiol. Biotechnol. 33:197. doi: 10.1007/s11274-017-2364-9

Omomowo, I. O., Shittu, O. E., Omomowo, O. I., and Majolagbe, O. N. (2020). Influence of phosphate solubilizing non-toxigenic Aspergillus flavus strains on maize (Zea mays L.) growth parameters and mineral nutrients content. AIMS Agric. Food 5, 408-421. doi: 10.3934/agrfood.2020.3.408

Ordentlich, A., Elad, Y., and Chet, I. (1988). The role of chitinase of Serratia marcescens in biocontrol of Sclerotium rolfsii. Phytopathology 78, 84-88.

Ordoñez, Y. M., Fernandez, B. R., Lara, L. S., Rodriguez, A., Uribe-Velez, D., and Sanders, I. R. (2016). Bacteria with phosphate solubilizing capacity alter mycorrhizal fungal growth both inside and outside the root and in the presence of native microbial communities. PLoS One 11:e154438. doi: 10.1371/journal.pone.0154438

Orozco-Mosqueda, M., Flores, A., Rojas-Sánchez, B., Urtis-Flores, C. A., Morales-Cedeño, L. R., Valencia-Marin, M. F., et al. (2021). Plant growthpromoting bacteria as bioinoculants: attributes and challenges for sustainable crop improvement. Agronomy 11:1167. doi: 10.3390/agronomy11061167

Pande, A., Kaushik, S., Pandey, P., and Negi, A. (2020). Isolation, characterization, and identification of phosphate-solubilizing Burkholderia cepacia from the sweet corn cv. Golden bantam rhizosphere soil and effect on growth-promoting activities. Int. J. Veg. Sci. 26, 591-607. doi: 10.1080/19315260.2019.1692121 
Pandey, S., and Gupta, S. (2020). Evaluation of pseudomonas sp. for its multifarious plant growth promoting potential and its ability to alleviate biotic and abiotic stress in tomato (Solanum lycopersicum) plants. Sci. Rep. 10:20951. doi: 10.1038/s41598-020-77850-0

Pandya, N. D., Desai, P. V., Jadhav, H. P., and Sayyed, R. Z. (2018). Plant growth promoting potential of aspergillus sp. NPF7, isolated from wheat rhizosphere in South Gujarat, India. Environ. Sustain. 1, 245-252. doi: 10.1007/s42398-018-0025-Z

Patel, P., and Panchal, K. (2020). Effect of free-living nitrogen fixing and phosphate solubilizing bacteria on growth of Gossypium hirsutum L. Asian J. Biol. Life Sci. 9, 169-176. doi: 10.5530/ajbls.2020.9.26

Pereira, S. I. A., Abreu, D., Moreira, H., Vega, A., and Castro, P. M. L. (2020). Plant growth-promoting rhizobacteria (PGPR) improve the growth and nutrient use efficiency in maize (Zea mays L.) under water deficit conditions. Heliyon 6:e05106. doi: 10.1016/j.heliyon.2020.e05106

Pikovskaya, R. I. (1948). Mobilization of phosphorus in soil in connection with vital activity of some microbial species. Mikrobiologiya 17, 362-370.

Prakash, J., and Arora, N. K. (2019). Phosphate-solubilizing Bacillus sp. enhances growth, phosphorus uptake and oil yield of Mentha arvensis L. 3 Biotech 9:126. doi: 10.1007/s13205-019-1660-5

Prom, L. K., Perumal, R., Montes-Garcia, N., Isakeit, T., Odvody, G. N., Rooney, W. L., et al. (2015). Evaluation of Gambian and Malian sorghum germplasm against downy mildew pathogen, Peronosclerospora sorghi, in Mexico and the USA. J. Gen. Plant Pathol. 81, 24-31. doi: 10.1007/ s10327-014-0557-8

Qarni, A., Billah, M., Hussain, K., Shah, S. H., Ahmed, W., Alam, S., et al. (2021). Isolation and characterization of phosphate solubilizing microbes from rock phosphate mines and their potential effect for sustainable agriculture. Sustainability 13:2151. doi: 10.3390/su13042151

Qiao, H., Sun, X.-R., Wu, X.-Q., Li, G.-E., Wang, Z., and Li, D.-W. (2019). The phosphate-solubilizing ability of Penicillium guanacastense and its effects on the growth of Pinus massoniana in phosphate-limiting conditions. Biol. Open 8:bio046797. doi: 10.1242/bio.046797

Raaijmakers, J. M., and Mazzola, M. (2012). Diversity and natural functions of antibiotics produced by beneficial and plant pathogenic bacteria. Annu. Rev. Phytopathol. 50, 403-424. doi: 10.1146/annurev-phyto-081211172908

Ramadhani, I., and Widawati, S. R. I. (2020). Synergistic interaction of arbuscular mycorrhizal fungi and phosphate-solubilizing bacteria on Sorghum bicolor (L.) moench growth under saline condition. Microbiol. Indones. 14, 73-82. doi: $10.5454 / \mathrm{mi} .14 .2 .4$

Rezakhani, L., Motesharezadeh, B., Tehrani, M. M., Etesami, H., and Hosseini, H. M. (2020). Effect of silicon and phosphate-solubilizing bacteria on improved phosphorus (P) uptake is not specific to insoluble P-fertilized sorghum (Sorghum bicolor L.) plants. J. Plant Growth Regul. 39, 239-253. doi: 10.1007/ s00344-019-09978-x

Rfaki, A., Zennouhi, O., Aliyat, F. Z., Nassiri, L., and Ibijbijen, J. (2020). Isolation, selection and characterization of root-associated rock phosphate solubilizing bacteria in moroccan wheat (Triticum aestivum L.). Geomicrobiol J. 37, 230-241. doi: 10.1080/01490451.2019.1694106

Ribeiro, V. P., Marriel, I. E., de Sousa, S. M., Lana, U. G. P., Mattos, B. B., de Oliveira, C. A., et al. (2018). Endophytic bacillus strains enhance pearl millet growth and nutrient uptake under low-P. Braz. J. Microbiol. 49, 40-46. doi: 10.1016/j.bjm.2018.06.005

Rizvi, A., Zaidi, A., Ameen, F., Ahmed, B., AlKahtani, M. D. F., and Khan, M. S. (2020). Heavy metal induced stress on wheat: phytotoxicity and microbiological management. RSC Adv. 10, 38379-38403. doi: 10.1039/D0RA05610C

Roy, P. R. S., and Khandaker, Z. H. (2010). Effects of phosphorus fertilizer on yield and nutritional value of sorghum (Sorghum bicolor) fodder at three cuttings. Bangladesh J. Anim. Sci. 39, 106-115. doi: 10.3329/BJAS.V39I1-2.9683

Saïdou, A., Balogoun, I., Ahoton, E. L., Igué, A. M., Youl, S., Ezui, G., et al. (2018). "Fertilizer recommendations for maize production in the South Sudan and Sudano-Guinean zones of Benin," in Improving the Profitability, Sustainability and Efficiency of Nutrients Through Site Specific Fertilizer Recommendations in West Africa Agro-Ecosystems. eds. A. Bationo, D. Ngaradoum, S. Youl, F. Lompo and J. O. Fening (Switzerland: Springer Nature), 215-234.

Saif, S., Khan, M. S., Zaidi, A., and Ahmad, E. (2014). "Role of phosphatesolubilizing actinomycetes in plant growth promotion: current perspective," in Phosphate Solubilizing Microorganisms. eds. M. Khan, A. Zaidi and J. Musarrat (Switzerland: Springer Nature), 137-156.

Sandy, M., and Butler, A. (2009). Microbial iron acquisition: marine and terrestrial siderophores. Chem. Rev. 109, 4580-4595. doi: 10.1021/cr9002787

Santana, S. R. A., Voltolini, T. V., dos Reis Antunes, G., da Silva, V. M., Simões, W. L., Morgante, C. V., et al. (2020). Inoculation of plant growthpromoting bacteria attenuates the negative effects of drought on sorghum. Arch. Microbiol. 202, 1015-1024. doi: 10.1007/s00203-020-01810-5

Saraf, M., Pandya, U., and Thakkar, A. (2014). Role of allelochemicals in plant growth promoting rhizobacteria for biocontrol of phytopathogens. Microbiol. Res. 169, 18-29. doi: 10.1016/j.micres.2013.08.009

Sarr, P. S., Tibiri, E. B., Fukuda, M., Zongo, A. N., and Nakamura, S. (2020). Phosphate-solubilizing fungi and alkaline phosphatase trigger the $\mathrm{P}$ solubilization during the co-composting of sorghum straw residues with Burkina Faso phosphate rock. Front. Environ. Sci. 8:559195. doi: 10.3389/ fenvs.2020.559195

Saxena, J., Chandra, S., and Nain, L. (2013). Synergistic effect of phosphate solubilizing rhizobacteria and arbuscular mycorrhiza on growth and yield of wheat plants. J. Soil Sci. Plant Nutr. 13, 511-525. doi: 10.4067/ S0718-95162013005000040

Sayyed, R. Z., Naphade, B. S., and Chincholkar, S. B. (2004). Ecologically competent rhizobacteria for plant growth promotion and disease management. Recent Trends Biotechnol. 1-16.

Sayyed, R. Z., and Patel, P. R. (2011). Biocontrol potential of siderophore producing heavy metal resistant Alcaligenes sp. and Pseudomonas aeruginosa RZS3 Vis-a-Vis organophosphorus fungicide. Indian J. Microbiol. 51, 266-272. doi: 10.1007/s12088-011-0170-x

Sebnie, W., Mengesha, M., Girmay, G., Feyisa, T., Asgedom, B., Beza, G., et al. (2020). Evaluation of micro-dosing fertilizer application on sorghum (sorghum bicholor L) production at wag-Lasta areas of Amhara region, Ethiopia. Sci. Rep. 10:6889. doi: 10.1038/s41598-020-63851-6

Selvakumar, G., Joshi, P., Nazim, S., Mishra, P. K., Bisht, J. K., and Gupta, H. S. (2009). Phosphate solubilization and growth promotion by Pseudomonas fragi CS11RH1 (MTCC 8984), a psychrotolerant bacterium isolated from a high altitude Himalayan rhizosphere. Biologia 64, 239-245. doi: 10.2478/ s11756-009-0041-7

Shahidi, F., and Naczk, M. (1995). Food phenolics: sources, chemistry, effects and aplications technomic publishing. Inc. P. 247:260.

Sharma, H. C. (1985). Strategies for pest control in sorghum in India. Int. J. Pest Manag. 31, 167-185.

Sharma, A., Kumar, V., Sidhu, G. P. S., Kumar, R., Kohli, S. K., Yadav, P., et al. (2019). "Abiotic stress management in plants: role of ethylene," in Molecular Plant Abiotic Stress: Biology and Biotechnology. eds. A. Roychoudhury and D. K. Tripathi (New Jersey, USA: John Wiley \& Sons), 185-208.

Shenoy, V. V., and Kalagudi, G. M. (2005). Enhancing plant phosphorus use efficiency for sustainable cropping. Biotechnol. Adv. 23, 501-513. doi: 10.1016/j. biotechadv.2005.01.004

Shete, M. H., Murumkar, D. R., Indi, D. V., and Tirmali, A. M. (2018). Effect of drought tolerant strains of phosphate solubilizing bacteria on growth and yield of Rabi sorghum. Indian J. Dryl. Agric. Res. Dev. 33, 59-63. doi: 10.5958/2231-6701.2018.00011.8

Shimshoni, J. A., Cuneah, O., Sulyok, M., Krska, R., Sionov, E., Barel, S., et al. (2017). Newly discovered ergot alkaloids in sorghum ergot Claviceps africana occurring for the first time in Israel. Food Chem. 219, 459-467. doi: 10.1016/j. foodchem.2016.09.182

Shoemaker, C. E., and Bransby, D. I. (2010). "The role of sorghum as a bioenergy feedstock," in Sustainable Alternative Fuel Feedstock Opportunities, Challenges and Road maps for Six US Regions. Proceeedings of the Sustainable Feedstocks for Advance Biofuels Workshop, Atlanta, GA. eds. R. Braun, D. Karlen and D. Johnson; September 28-30, 2010; Soil and Water Conserv. Soc., Ankeny, IA; $149-159$.

Silveira, A. A. C., de Araújo, L. G., de Filippi, M. C. C., de Faria, F. P., and Sibov, S. T. (2021). Biochemical characterization of multifunctional endophytic fungi from Bambusa oldhamii Munro. Pesqui. Agropecuária Trop. 50, 1-8. doi: $10.1590 / 1983-40632020 v 5066370$

Singh, N., Pandey, P., Dubey, R. C., and Maheshwari, D. K. (2008). Biological control of root rot fungus Macrophomina phaseolina and growth enhancement of Pinus roxburghii (Sarg.) by rhizosphere competent Bacillus subtilis BN1. World J. Microbiol. Biotechnol. 24, 1669-1679. doi: 10.1007/s11274-008-9680-z 
Singh, P. P., Shin, Y. C., Park, C. S., and Chung, Y. R. (1999). Biological control of fusarium wilt of cucumber by chitinolytic bacteria. Phytopathology 89, 92-99. doi: 10.1094/PHYTO.1999.89.1.92

Soumare, A., Boubekri, K., Lyamlouli, K., Hafidi, M., Ouhdouch, Y., and Kouisni, L. (2020). From isolation of phosphate solubilizing microbes to their formulation and use as biofertilizers: status and needs. Front. Bioeng. Biotechnol. 7:425. doi: 10.3389/fbioe.2019.00425

Srinivasan, R., Alagawadi, A. R., Yandigeri, M. S., Meena, K. K., and Saxena, A. K. (2012). Characterization of phosphate-solubilizing microorganisms from saltaffected soils of India and their effect on growth of sorghum plants [Sorghum bicolor (L.) Moench]. Ann. Microbiol. 62, 93-105. doi: 10.1007/s13213-011-0233-6

Steiner, F., Lana, M. D. O. C., and Zoz, T. (2016). Phosphate solubilizing fungi enhance the growth and phosphorus uptake of sorghum plants. Rev. Bras. Milho Sorgo 15, 30-38. doi: 10.18512/1980-6477/rbms.v15n1p30-38

Tandon, A., Fatima, T., Shukla, D., Tripathi, P., Srivastava, S., and Singh, P. C. (2020). Phosphate solubilization by Trichoderma koningiopsis (NBRI-PR5) under abiotic stress conditions. J. King Saud Univ. 32, 791-798. doi: 10.1016/j. jksus.2019.02.001

Tari, I., Laskay, G., Takács, Z., and Poór, P. (2013). Response of sorghum to abiotic stresses: a review. J. Agron. Crop Sci. 199, 264-274. doi: 10.1111/jac.12017

Tasie, M. M., and Gebreyes, B. G. (2020). Characterization of nutritional, antinutritional, and mineral contents of thirty-five sorghum varieties grown in Ethiopia. Int. J. Food Sci. 2020:8243617. doi: 10.1155/2020/8243617

Tian, J., Ge, F., Zhang, D., Deng, S., and Liu, X. (2021). Roles of phosphate solubilizing microorganisms from managing soil phosphorus deficiency to mediating biogeochemical P cycle. Biology 10:158. doi: 10.3390/biology10020158

Toomey, G. (1988). Sorghum as substitute: food enterprises for Indian women. IDRC Reports, 17, no. 3.

Venkateswarlu, B., Rao, A. V., and Raina, P. (1984). Evaluation of phosphorus solubilisation by microorganisms isolated from Aridisols. J. Indian Soc. Soil Sci. 32, 273-277.

Verma, M., Singh, A., Dwivedi, D. H., and Arora, N. K. (2020). Zinc and phosphate solubilizing rhizobium radiobacter (LB2) for enhancing quality and yield of loose leaf lettuce in saline soil. Environ. Sustain. 3, 209-218. doi: 10.1007/s42398-020-00110-4

Verma, V. C., Singh, S. K., and Prakash, S. (2011). Bio-control and plant growth promotion potential of siderophore producing endophytic Streptomyces from Azadirachta indica A. Juss. J. Basic Microbiol. 51, 550-556. doi: 10.1002/ jobm. 201000155

Vijayalakshmi, V., Pradeep, S., Manjunatha, H., Krishna, V., and Jyothi, V. (2020). The impact of nitrogen fixers and phosphate solubilizing microbes on sorghum (Sorghum bicolor) yield. Curr. Biotechnol. 9, 198-208. doi: 1 $0.2174 / 2211550109666191218125559$

Vikram, A. (2007). Efficacy of phosphate solubilizing bacteria isolated from vertisols on growth and yield parameters of sorghum. Res. J. Microbiol. 2, 550-559. doi: 10.3923/jm.2007.550.559

Wagari, M. K. (2019). Importance and management of sorghum smuts with special reference to: the covered kernel smut (Sphacelotheca sorghi [Link] Clinton), Loose Kernel Smut (Sphacelotheca cruenta [Kuhn] Potter) and Head Smut (Sphacelotheca). Green. J. Agri. Sci. 9, 447-458.

Wahid, F., Sharif, M., Steinkellner, S., Khan, M. A., Marwat, K. B., and Khan, S. A. (2016). Inoculation of arbuscular mycorrhizal fungi and phosphate solubilizing bacteria in the presence of rock phosphate improves phosphorus uptake and growth of maize. Pak. J. Bot. 48, 739-747.

Walpola, B. C., and Yoon, M.-H. (2012). Prospectus of phosphate solubilizing microorganisms and phosphorus availability in agricultural soils: a review. Afr. J. Microbiol. Res. 6, 6600-6605.

Wan, W., Qin, Y., Wu, H., Zuo, W., He, H., Tan, J., et al. (2020). Isolation and characterization of phosphorus solubilizing bacteria with multiple phosphorus sources utilizing capability and their potential for lead immobilization in soil. Front. Microbiol. 11:752. doi: 10.3389/fmicb.2020.00752

Wang, X., Mace, E., Hunt, C., Cruickshank, A., Henzell, R., Parkes, H., et al. (2014). Two distinct classes of QTL determine rust resistance in sorghum. BMC Plant Biol. 14:366. doi: 10.1186/s12870-014-0366-4

Wang, Q., Shakoor, N., Boyher, A., Veley, K. M., Berry, J. C., Mockler, T. C., et al. (2021). Escalation in the host-pathogen arms race: a host resistance response corresponds to a heightened bacterial virulence response. PLoS Pathog. 17:e1009175. doi: 10.1371/journal.ppat.1009175
Wang, Q., Wang, C., Yu, W., Turak, A., Chen, D., Huang, Y., et al. (2018). Effects of nitrogen and phosphorus inputs on soil bacterial abundance, diversity, and community composition in Chinese fir plantations. Front. Microbiol. 9:3354. doi: 10.3389/fmicb.2018.03354

Weller, D. M., Landa, B. B., Mavrodi, O. V., Schroeder, K. L., De La Fuente, L., Bankhead, S. B., et al. (2007). Role of 2, 4-diacetylphloroglucinol-producing fluorescent pseudomonas spp. in the defense of plant roots. Plant Biol. 9, 4-20. doi: 10.1055/s-2006-924473

Widada, J., Damarjaya, D. I., and Kabirun, S. (2007). "The interactive effects of arbuscular mycorrhizal fungi and rhizobacteria on the growth and nutrients uptake of sorghum in acid soil," in First International Meeting on Microbial Phosphate Solubilization. eds. E. Velázquez and C. Rodríguez-Barrueco (Switzerland: Springer Nature), 173-177.

Xu, J., Jiang, Y., Hu, L., Liu, K.-J., Xu, X.-D., Qin, P.-W., et al. (2019). First report of rough leaf spot of sorghum caused by Ascochyta sorghi in China. Plant Dis. 103:149. doi: 10.1094/PDIS-11-17-1850-PDN

Yadav, K. K., and Sarkar, S. (2019). Biofertilizers, impact on soil fertility and crop productivity under sustainable agriculture. Environ. Ecol. 37, 89-93.

Zafar, M., Ahmed, N., Mustafa, G., Zahir, Z. A., and Simms, E. L. (2017). Molecular and biochemical characterization of rhizobia from chickpea (Cicer arietinum). Pak. J. Agric. Sci. 54, 373-381. doi: 10.21162/PAKJAS/17.5874

Zaheer, A., Malik, A., Sher, A., Qaisrani, M. M., Mehmood, A., Khan, S. U., et al. (2019). Isolation, characterization, and effect of phosphate-zinc-solubilizing bacterial strains on chickpea (Cicer arietinum L.) growth. Saudi J. Biol. Sci. 26, 1061-1067. doi: 10.1016/j.sjbs.2019.04.004

Zaidi, A., Ahmad, E., and Khan, M. S. (2014). "Role of phosphate-solubilizing microbes in the management of plant diseases," in Phosphate Solubilizing Microorganisms. eds. M. Khan, A. Zaidi and J. Musarrat (Switzerland: Springer Nature), 225-256.

Zaidi, A., Khan, M., Ahemad, M., and Oves, M. (2009). Plant growth promotion by phosphate solubilizing bacteria. Acta Microbiol. Immunol. Hung. 56, 263-284. doi: 10.1556/AMicr.56.2009.3.6

Zhao, Z.-Y., Che, P., Glassman, K., and Albertsen, M. (2019). "Nutritionally enhanced sorghum for the arid and semiarid tropical areas of Africa," in Sorghum. eds. Z. Y. Zhao and J. Dahlberg (Switzerland: Springer Nature), 197-207.

Zhao, G., Wei, Y., Chen, J., Dong, Y., Hou, L., and Jiao, R. (2021). Screening, identification and growth-promotion products of multifunctional bacteria in a Chinese fir plantation. Forests 12:120. doi: 10.3390/f12020120

Zhu, J., Li, M., and Whelan, M. (2018). Phosphorus activators contribute to legacy phosphorus availability in agricultural soils: a review. Sci. Total Environ. 612, 522-537. doi: 10.1016/j.scitotenv.2017.08.095

Ziaeyan, H., Farahbakhash, A. R., Besharati, H., and Joukar, L. (2016). Interaction effects of phosphate solubilizing bacteria and mycorrhiza on the growth and phosphorus uptake of sorghum. J. Water Soil 30:5.

Zúñiga-Silgado, D., Rivera-Leyva, J. C., Coleman, J. J., Sánchez-Reyez, A., Valencia-Díaz, S., Serrano, M., et al. (2020). Soil type affects organic acid production and phosphorus solubilization efficiency mediated by several native fungal strains from Mexico. Microorganisms 8:1337. doi: 10.3390/ microorganisms 8091337

Conflict of Interest: The authors declare that the research was conducted in the absence of any commercial or financial relationships that could be construed as a potential conflict of interest.

Publisher's Note: All claims expressed in this article are solely those of the authors and do not necessarily represent those of their affiliated organizations, or those of the publisher, the editors and the reviewers. Any product that may be evaluated in this article, or claim that may be made by its manufacturer, is not guaranteed or endorsed by the publisher.

Copyright (c) 2021 Rizvi, Ahmed, Khan, Umar and Lee. This is an open-access article distributed under the terms of the Creative Commons Attribution License (CC BY). The use, distribution or reproduction in other forums is permitted, provided the original author(s) and the copyright owner(s) are credited and that the original publication in this journal is cited, in accordance with accepted academic practice. No use, distribution or reproduction is permitted which does not comply with these terms. 